\title{
The Antitrust-Telecom Connection
}

\author{
STEVEN SEMERARO*
}

\section{TABLE OF CONTENTS}

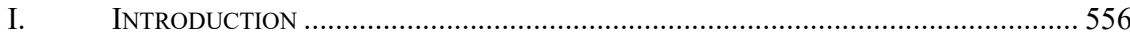

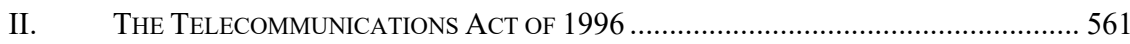

A. Events Leading to the Enactment of the Telecom Act ............................... 561

B. The Telecom Act's Local Competition Provisions .................................... 562

C. $\quad$ The Telecom-Antitrust Complaints ....................................................... 564

III. The LAW OF ANTITRUST-Regulatory ACCOMMODATION

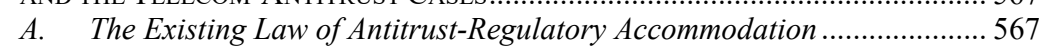

1. Implied Immunities Are Disfavored ................................................ 568

2. Regulated Conduct Supervised by Public Actors

Falls Outside the Scope of the Antitrust Laws ................................ 569

B. Court and Agency Analysis in the Telecom-Antitrust

Cases Rests on These Doctrines................................................................ 573

1. The Second and Eleventh Circuits Rely on the Implied Immunity Doctrine ......................................................... 573

2. The Seventh Circuit and Most Lower Courts Implicitly Rely on Government Oversight ........................................ 575

a. The Goldwasser Decision and Its Progeny ................................. 576

b. Interpreting Goldwasser and Its Progeny................................ 579

$i$. The Fully Contextual Nature of Antitrust Analysis.

ii. Regulation and Government Supervision........................... 584

* Associate Dean and Associate Professor of Law, Thomas Jefferson School of Law; former trial attorney and consulting attorney with the United States Department of Justice, Antitrust Division. The author would like to thank Eric Mitnick and Phil Weiser for their encouragement and helpful comments on earlier drafts and Dorothy Hampton, June MacLeod, and Kimberly Reisman for their excellent research assistance. 
IV. Six Degrees of CONNECTION Between Competition-

ENHANCING, INDUSTRY-SPECIFIC REGULATORY STATUTES

AND THE ANTITRUST LAWS .....

A. Distinguishing Existing Doctrine ........................................................... 588

B. Developing Accommodation Doctrine for Competition-

Enhancing Regulation........................................................................... 589

1. Whether Antitrust Enforcement Would Interfere

with a Procompetitive Regulatory Program .................................... 591

a. Focusing on How Imposing Antitrust Duties

Would Affect Regulatory Duties.............................................. 591

b. Rejecting Antitrust in Favor of Competition-

Enhancing Regulation.......................................................... 592

2. How Regulation Affects Antitrust .................................................. 593

a. The Neutrality Position .............................................................. 596

b. Treating Regulatory Violations as Predatory Acts

Where Market Power Is Shown and the Defendant

Has Inadequate Procompetitive Justifications ............................ 596

c. Identifying Predatory Acts Unless a Procompetitive

Purpose Is Proven.

d. Acts that Are Predatory Per Se if Market Power

Is Proven....................................................................................... 598

e. Per Se Condemnation ........................................................ 598

V. Separation BetweEn the Telecom ACt AND THE

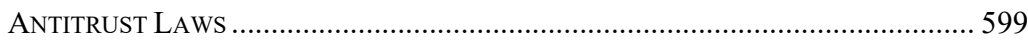

A. Imposing Antitrust Duties Would Not Undermine the

Effectiveness of the Telecom Act ............................................................... 599

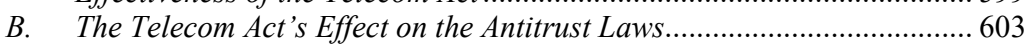

1. Rejecting the Extreme Forms of Antitrust-

Telecom Connection ...

2. Choosing Among the Final Three Degrees of

Connection Requires More Careful Analysis .................................. 604

a. Plaintiffs Must Prove Market Power for ILEC-Specific Duties, But Not for All LEC Duties.

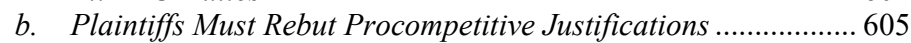

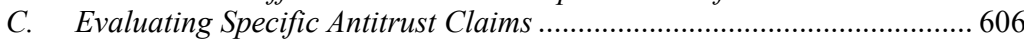

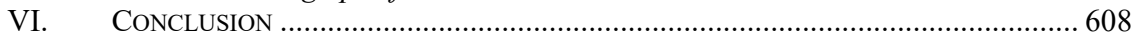

\section{INTRODUCTION}

Courts have always had a special role in making competition policy. The open-textured language of the Sherman $\mathrm{Act}^{1}$ and other antitrust laws has forced courts to fill a policy-making void that Congress has-with rare exception-shown little desire to take back. ${ }^{2}$ When Congress has

\footnotetext{
1. Sherman Antitrust Act, 15 U.S.C. $\S \S 1-7$ (2000).

2. As Robert Bork wrote:

The central institution in making antitrust law has been the Supreme Court.

That is true because the antitrust laws are so open-textured, leave so much to be

filled in by the judiciary, that the Court plays in antitrust almost as unconstrained
} 
enacted regulatory legislation, it has traditionally relied on methods other than marketplace competition to achieve its goals.

The Telecommunications Act of $1996^{3}$ breaks from that historical paradigm. The Act is legislative competition policy-making that stimulates rivalry in local telephone service principally by requiring "incumbent local exchange carriers" (ILECs), the existing local telephone companies, to interconnect with, and provide certain services to "competitive local exchange carriers" (CLECs). ${ }^{4}$ When market entry emerged more slowly than many had hoped, CLECs and consumers sued the ILECs. The claims alleged that the ILECs failed to fulfill their duties under the Telecom Act by unlawfully maintaining their monopoly power in the local telephone service market in violation of section 2 of the Sherman Act. ${ }^{5}$ A CLEC executive described the genesis of one of these

a role as it does in constitutional law.... [E]ven if courts accept consumer welfare as their sole guideline, they have been granted an exceptionally broad mandate to make law.

Robert H. Bork, The Antitrust Paradox: A Policy At War with Itself 409 (1978) (footnote omitted). While the language of the Clayton Act is somewhat clearer than that of the Sherman Act, the court's role is no less ambitious because "Congress has indicated its belief that [certain practices] may - not always, but under circumstances deliberately left undefined-injure competition." Id. Courts are thus left with the goal of making the policy choices. See IA Phillip ArEeda \& Herbert HovenKamp,

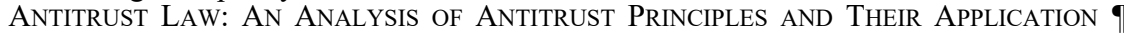
$240 \mathrm{c} 3$ (2d ed. 1997) (recognizing that antitrust cases often turn "on a court's judgment about the degree of social harm that might result from the challenged practice, the social benefits that might be obtained through that practice, and the availability of significantly less restrictive alternatives").

3. Telecommunications Act of 1996, Pub. L. No. 104-104, 110 Stat. 56 (codified as amended in scattered sections of 15 U.S.C. and 47 U.S.C.). Throughout this Article, the Telecommunications Act of 1996 is also referred to as "the Telecom Act" or "the 1996 Act.”

4. The preamble to the Act states that it was designed "to promote competition and reduce regulation in order to secure lower prices and higher quality services for American telecommunications consumers and encourage the rapid deployment of new telecommunications technologies." Id. The House Conference Report explained that the purpose of the Act was "to provide for a pro-competitive, de-regulatory national policy framework designed to accelerate rapidly private sector deployment of advanced telecommunications and information technologies and services... by opening all telecommunications markets to competition ...." H.R. CONF. REP. NO. 104-458, at 1 (1996).

5. Covad Communications Co. v. Bell Atl. Corp., 201 F. Supp. 2d 123, 129 (D.D.C. 2002); Nicholas Kulish et al., Ruling Opens Baby Bells Up to Suits: Court Lets Customers Sue Local Phone Companies for Antitrust Violations, WALL ST. J., June 21, 2002, at A3 (referring to "dozens of lawsuits Bell competitors have filed against the regional phone companies"); Pulver.Com, Telecom Antitrust Intelligence Report, available at http://www.pulver.com/antitrustreport/research.html (last visited Nov. 18, 2002) (listing complaints filed and pleadings); Gail Lawyer, The Last Resort: Competitors 
cases - though he could have been referring to any of them-by commenting that the ILEC "was trying to put us out of business like they did all the other CLECs .... [The conduct of the ILEC] is costing consumers in the states we serve billions of dollars in lost potential savings." judicial response to these cases has been perplexing. Each court claims to be applying the same law; all of the judges write with utter confidence in the correctness of their analysis; ${ }^{7}$ and yet the courts reach two diametrically opposite results. The Second and Eleventh Circuits have held that the antitrust laws apply to local telephone companies as if the 1996 Act did not exist. ${ }^{8}$ But the Seventh Circuit and several district courts have dismissed identical antitrust claims. ${ }^{9}$ The Supreme Court recently granted certiorari to resolve this dispute. ${ }^{10}$

Turn to Antitrust Actions Amid Mounting Frustration with '96 Act, XCHANGE MagazINE (July 1, 2001), at http://www.xchangemag.com/articles/171 front.html (identifying recent antitrust cases)

6. Lawyer, supra note 5 (quoting Keith Machen, Vice President of Ntegrity, charging Verizon with antitrust violations).

7. For example, in Covad's case against BellSouth, Judge Martin recognized that the Federal Communications Commission (FCC) and the Department of Justice (DOJ) had disagreed with the Seventh Circuit's holding that antitrust claims could not be based on conduct relating to duties created by the 1996 Act. Covad Communications Co. v. BellSouth Corp., No. 1:00-CV-3414, slip op. at 25 (N.D. Ga. July 6, 2001) (recognizing that the DOJ and the FCC believed that antitrust claims "should be available for failing to perform duties under the 1996 Act"). But Judge Martin rejected their views quite abruptly, writing that "[i]f Congress ... desire[s] to amend the 1996 Act... to specifically include antitrust remedies for failing to perform affirmative duties, then [it] may do so. In the meantime, this court's role is to apply the current, correct and logical interpretation of the 1996 Act and the Sherman Act." Id.

8. See infra Part III.B.1. The Second Circuit's holding was limited to cases initiated by consumers. Law Offices of Curtis V. Trinko, L.L.P. v. Bell Atl. Corp., 305 F.3d 89, 112 n.19 (2d Cir. 2002) ("Our decision does not address whether LECs seeking to enter the market may ever bring antitrust suits against the ILEC."). While the Second Circuit reserved judgment with respect to cases filed by CLECs, which represent a majority of the cases, the court's analysis is mirrored in the Eleventh Circuit's decision in Covad Communications Co. v. BellSouth Corp., 299 F.3d 1272, 1280 (11th Cir. 2002), and in amicus briefs filed jointly by the Antitrust Division of the DOJ and the FCC in cases that were initiated by competitors. See Brief of Amici Curiae United States and the Federal Communications Commission as Amici Curiae at 13, Covad Communications Co. v. BellSouth Corp., 299 F.3d 1272 (11th Cir. 2002) (No. 01-16064-C); Brief for the United States and Federal Communications Commission as Amici Curiae in Support of Appellants at 10-11, Intermedia Communications, Inc. v. BellSouth Telecomms., Inc., (11th Cir. filed Jan. 12, 2001) (No. 01-10224-JJ).

9. See infra Part III.B.2. Judge Tjoflat, in an opinion dissenting from the denial of rehearing en banc in the Eleventh Circuit Covad case, expressed agreement with these courts. Covad Communications Co. v. BellSouth Corp., 314 F.3d 1282, 1288-90 (11th Cir. 2002) (Tjoflat, J., dissenting).

10. Verizon Communications v. Law Offices of Curtis V. Trinko, L.L.P., 123 S. Ct. 1480 (2003) (mem.) (limiting grant of certiorari to the question: "Did the Court of Appeals err in reversing the District Court's dismissal of respondent's antitrust claims?"). 
This Article has two purposes: (1) to explain these conflicting results, and (2) to propose a method to determine the appropriate degree of connection between the antitrust laws and an industry-specific regulatory statute that, like the Telecom Act, seeks to enhance competition. The conflicting results in the telecom-antitrust cases arise because the courts are struggling to deal with legislative competition policy-making. The old strains of antitrust-regulatory accommodation doctrine were designed for situations in which the legislature sought to advance public policy goals other than competition. ${ }^{11}$ By contrast, accommodating the 1996 Act requires the court to determine how best to achieve the single goal of enhancing competition. None of the courts deciding telecomantitrust cases have recognized that this distinction creates the need for different doctrinal tools. ${ }^{12}$

Harmonizing antitrust and competition-enhancing, industry-specific regulation requires careful contextual analysis. To say, as the Seventh Circuit has, that the specific duties and regulatory structures created by the Telecom Act displace antitrust scrutiny begs the question: Would displacement of the antitrust laws help achieve the Telecom Act's goal of stimulating competition in local telephone service? It would be odd for Congress to displace antitrust enforcement if it did not. Similarly, to say, as the Second and Eleventh Circuits have, that antitrust continues to apply as if there were no Telecom Act begs the same question: Would

11. To be sure, regulation has often sought to protect consumers from price gouging, which is one of the goals of antitrust and competition policy. But traditional consumer-welfare-oriented regulation relied on a direct price control mechanism of one sort or another rather than marketplace competition to achieve its goals. Further, competition-enhancing policy has much broader goals than preventing price gouging. See Fed. Trade Comm'n v. Superior Court Trial Lawyers Ass'n, 493 U.S. 411, 423-24 (1990).

$[\mathrm{T}]$ he "Sherman Act reflects a legislative judgment that ultimately competition

will produce not only lower prices, but also better goods and services." This

judgment "recognizes that all elements of a bargain-quality, service, safety,

and durability - and not just the immediate cost, are favorably affected by the

free opportunity to select among alternative offers."

Id. (quoting Nat'l Soc'y of Prof'l Eng'rs v. United States, 435 U.S. 679, 695 (1978)); N. Pac. Ry. Co. v. United States, 356 U.S. 1, 4 (1958) (explaining that antitrust law "rests on the premise that the unrestrained interaction of competitive forces will yield the best allocation of our economic resources, the lowest prices, the highest quality and the greatest material progress").

12. See infra note 34. As of the time of this writing, the one commentary on this type of litigation similarly fails to perceive this distinction. See Megan Delany, The Dominos of Goldwasser: Only Congress Can Stop the Toppling Effect Before the Game Is Over, 10 J. COMM. L. \& POL'Y 279, 292-97 (2002) (concluding that Goldwasser was wrongly decided without considering antitrust-regulatory accommodation doctrine). 
simply overlaying antitrust enforcement on top of competitionenhancing regulation advance the goal of spurring competition? It depends. The regulation may carefully structure an industry in ways that could be undone if standard antitrust duties were imposed. In such a case, courts should refrain from applying antitrust law. In other cases, regulation may enable the courts to apply the antitrust laws more aggressively. By declaring that certain conduct is anticompetitive within the regulated industry, the legislature makes competition policy-it creates a bright line that minimizes the concern that aggressive enforcement would chill procompetitive behavior.

This Article explores six ways that courts might account for a competition-enhancing regulatory statute when considering an antitrust challenge. These six degrees of connection range from creating a blanket exemption from antitrust attack to treating violations of the regulatory statute as per se antitrust violations. In choosing among these options, a court should engage in a two-step analysis. First, it should ask whether recognizing antitrust duties concurrently with regulatory duties would reduce the regulatory statute's effectiveness in fostering competition. If it would, then the court should find that the regulated conduct falls outside the scope of antitrust. If antitrust enforcement would not hinder the regulation's effectiveness, the court should proceed to the second step and ask how, if at all, the duties created by the regulation should affect antitrust analysis.

A court applying this test in a telecom-antitrust case should find, at the first step, that the 1996 Act would be enhanced if the court also imposed antitrust duties on ILECs. At the second step, the court should find that a plaintiff, who proves that an ILEC with market power has violated a nontrivial regulatory duty imposed by the 1996 Act, is entitled to a presumption that the violation substantially contributed to the maintenance of the ILEC's market power. The language and structure of the 1996 Act, however, indicate that defendants should retain the right to show that there are procompetitive reasons for violating a duty imposed by the 1996 Act, and plaintiffs should retain the burden of rebutting those justifications.

Part II of this Article introduces the Telecommunications Act of 1996, focusing on the provisions that are intended to stimulate competition in local telephone service. It then summarizes the allegations in the telecom-antitrust cases. Part III sets out the established law of antitrustregulatory accommodation and describes how the differing results in the telecom-antitrust cases can be explained by the courts'-sometimes explicit and sometimes implicit-reliance on two different lines of doctrine: implied immunity and antitrust state action. Part IV explains that neither doctrine is an appropriate analytical model for the telecom- 
antitrust cases because the Telecom Act, unlike the regulation considered in prior cases, is designed to enhance competition. This section then sets out the two-step inquiry to determine the appropriate degree of antitrustregulatory connection. Part V applies that analysis to the Telecom Act.

\section{The TELECOMMUNICATIONS ACT OF 1996}

This Part briefly traces the events leading up to the 1996 Act and describes the Act's local competition provisions. It then summarizes the various antitrust cases that have been filed against the ILECs.

\section{A. Events Leading to the Enactment of the Telecom Act}

A summary of the Telecom Act's local competition provisions must start with the 1984 breakup of the American Telephone and Telegraph Company (AT\&T). Through the early 1980s, virtually all telephone service in the United States was provided by regulated monopolies. By the end of the decade, much had changed. Public and private antitrust cases against AT\&T led to a restructuring of the telephony industry under the auspices of a consent decree known as the "modified final judgment" (MFJ). ${ }^{13}$ That decree sought to stimulate competition in long distance telephone service by stripping AT\&T of its local service monopolies and forcing it to compete on a more level playing field with MCI and other competitive entrants into the long distance telephone service market. ${ }^{14}$

13. MCI Communications Corp. v. Am. Tel. \& Tel. Co., 708 F.2d 1081, 1132-33 (7th Cir. 1983) (holding that local distribution facilities were "essential facilities" and therefore AT\&T must provide MCI access to them); United States v. Am. Tel. \& Tel. Co., 552 F. Supp. 131, 195-200 (D.D.C. 1982), aff'd mem. sub nom., Maryland v. United States, 460 U.S. 1001 (1983) (approving a consent decree that imposed on local service providers a duty to share access to local telephone networks with competitive long distance providers). For an analysis of the legal theories undermining the cases see Roger G. Noll \& Bruce M. Owen, The Anticompetitive Uses of Regulation: United States v. AT\&T, in The Antitrust Revolution 290, 295-326 (John E. Kwoka, Jr. \& Lawrence J. White eds., 1989).

14. "[A]ccess to AT\&T's local network is crucial if long distance carriers ... are to be viable competitors." Am. Tel. \& Tel. Co., 552 F. Supp. at 223. The divestiture of the local operating companies from the Bell System "will sever the relationship between this local monopoly and the other, competitive segments of AT\&T, and it will thus ensure - certainly better than could any other type of relief - that the practices which allegedly have lain heavy on the telecommunications industry will not recur." Id. 
The MFJ divided AT\&T's local service operations into seven geographically separate companies. ${ }^{15}$ Each was a monopoly provider of local service in its own region, but the decree prohibited these local service providers from competing in the long distance market. ${ }^{16}$ The MFJ left local service in the hands of monopoly providers because the government then believed that efficient competition in the local market was not possible. ${ }^{17}$ By the 1990s, technological advancements had undermined the MFJ's assumption that competition could not exist at the local level. ${ }^{18}$ Congress concluded, however, that local competition would be unlikely to emerge in the short term without industry-specific legislation. ${ }^{19}$

\section{B. The Telecom Act's Local Competition Provisions}

In 1996 Congress acted. The Telecom Act supplanted the MFJ with a new framework designed to increase competition throughout the telecommunications industry, but particularly with respect to local telephone service. ${ }^{20}$ The Act prohibited states from enforcing regulatory statutes that blocked competitive entry into local service markets ${ }^{21}$ and imposed a series of affirmative duties on local telephone companies, beginning with a general duty to interconnect. ${ }^{22}$ The Act also imposed specific duties including:

15. Id. at $141,142 \& \mathrm{n} .41$.

16. Id. at 143 .

17. AT\&T Corp. v. Iowa Utils. Bd., 525 U.S. 366, 413-14 (1999) (Breyer, J., concurring in part and dissenting in part); Law Offices of Curtis V. Trinko, L.L.P. v. Bell Atl. Corp., 305 F.3d 89, 93-94 (2d Cir. 2002) (explaining that "[t]he rationale for allowing monopolies in the local phone service market was the belief that having more than one local provider would lead to unwarranted duplication in the physical connecting wires through which local calls are transmitted"); United States v. W. Elec. Co., Inc., 673 F. Supp. 525, 537-38 (D.D.C. 1987); Peter Huber et AL., The GeOdDesic Network II: 1993 REPORT ON COMPETITION IN THE TELEPHONE INDUSTRY 2.3-2.5 (1992).

18. Iowa Utils. Bd., 525 U.S. at 371 ("Technological advances ... have made competition among multiple providers of local service seem possible ....”).

19. In re Implementation of the Local Competition Provisions in the Telecommunications Act of 1996, First Report and Order, 11 FCC Rcd. 15,508 (1996).

$[\mathrm{T}]$ he removal of statutory and regulatory barriers to entry into the local exchange and exchange access markets, while a necessary precondition to competition, is not sufficient to ensure that competition will supplant monopolies. ... Congress addressed these problems in the 1996 Act by mandating that the most significant economic impediments to efficient entry Id. into the monopolized local market must be removed.

20. See supra Part I; supra notes 4-5 and accompanying text.

21. 47 U.S.C. § 253(a) (2000); see Iowa Utils. Bd., 525 U.S. at 416 (Breyer, J., concurring in part and dissenting in part) (explaining that "the Act permits new local entry by dismantling existing legal barriers that would otherwise inhibit it").

22. 47 U.S.C. $\$ 251(\mathrm{a})$. 
(1) a ban on prohibiting the resale of telephone service,

(2) a requirement that customers who switch carriers be allowed keep their telephone numbers,

(3) a prohibition on discriminatory access requirements, such as the need to dial more numbers with certain providers,

(4) a duty to share access to rights of way for cable or wire, and

(5) a duty to enter "reciprocal compensation arrangements for the transport and termination of telecommunications."23

In addition to these general duties placed on all competitors in the local service market, Congress imposed additional obligations on the ILECs. It explicitly required them to negotiate in good faith with respect to the generally applicable requirements of the Act, ${ }^{24}$ and it created five specific positive duties:

(1) to interconnect with potential competitors "at any technically feasible point within the carrier's network ... that is at least equal in quality to that provided by the local exchange carrier to itself' or any other party,

(2) to provide potential competitors with unbundled access - at a cost-based royalty plus reasonable profit - to elements of the ILEC's own network,

(3) to offer for resale at wholesale rates any service that the ILEC provides to its customers,

(4) to notify other carriers of changes to the network that would affect interoperability with other networks, and

(5) to rent potential competitors the space needed for their interconnection and other necessary equipment. ${ }^{25}$

Recognizing that these provisions would require extensive cooperation among telecommunications providers, Congress required an ILEC to enter negotiations with a CLEC whenever interconnection was requested. ${ }^{26}$ The parties were permitted, but not required, to ask state regulators to participate as mediators in pursuit of a voluntary agreement. ${ }^{27}$ If an agreement was not reached between 135 and 160 days after the initial request, either party was empowered to seek compulsory arbitration by

23. Id. $\S 251(\mathrm{~b})$.

24. Id. $\S 251(\mathrm{c})(1)$.

25. Id. § 251(c)(2)-(6)

26. Id. $\$ 252(\mathrm{a})-(\mathrm{b})$.

27. Id. $\S 252(\mathrm{a})(2)$. 
state regulators, who must then resolve all open issues within nine months of the initial request. ${ }^{28}$ In all events, state regulatory commissions must approve all agreements and the FCC was empowered to step in if a state commission failed to fulfill its obligations. ${ }^{29}$ Once an agreement was in place, the specific terms of the agreement rather than the language of the statute would govern the relationship between the ILEC and the CLEC. ${ }^{30}$

The 1996 Act sought to encourage the ILECs to comply with the duties it imposed by permitting an ILEC to provide long distance service to its own local customers if it demonstrated that its local telephone service market was open to competition. ${ }^{31}$ To meet this obligation, an ILEC had to make available a "competitive checklist" of interconnection and related services. ${ }^{32}$ While this potential for entry into the long distance market provided a "carrot" to encourage ILECs to cooperate with competitors in local service markets, the 1996 Act was remarkably short of "sticks" to either compel compliance if an ILEC had little interest in providing long distance service or to ensure continued compliance once an ILEC satisfied the competitive checklist. ${ }^{33}$

\section{The Telecom-Antitrust Complaints}

Consumers and CLECs have charged the ILECs with monopolizing the local telephone service market by frustrating the procompetitive aims of the 1996 Act and thereby maintaining their own monopolistic position. To date, courts have ruled on at least a dozen motions to dismiss antitrust cases based on violations of the 1996 Act. $^{34}$ The cases

28. Id. § 252(b).

29. Id. $\$ 252(\mathrm{e})$.

30. Law Offices of Curtis V. Trinko, L.L.P. v. Bell Atl. Corp., 305 F.3d 89, 103 (2d Cir. 2002) (explaining that "[w]hile the duties regulating ILECs enumerated in subsections (b) and (c) of section 251 appear at first glance to be freestanding, in practice, section 251 envisions that these duties will be implemented through state approved contracts between the [CLEC] and the ILEC").

31. 47 U.S.C. $§ 271(b)(1)$, (c), (d)(3). The 1996 Act immediately permitted an ILEC to compete to provide long distance service to customers in regions in which it did not provide local service. Id. § 271(b)(2).

32. Id. § 271(c)(2)(B).

33. Joel I. Klein, The Race for Local Competition: A Long Distance Run, Not a Sprint, Address Before the American Enterprise Institute 7 (Nov. 5, 1997), at http://www.usdoj.gov/atr/public/speeches/1268.htm (then-Assistant Attorney General for the Antitrust Division of the DOJ describing the carrot and stick approach of the 1996 Act as follows: "As for the 'sticks,' there are real questions at this point; the Act itself calls for no real penalties for non-compliance ....").

34. Numerous cases dismissed antitrust claims based on violations of the 1996 Act. Covad Communications Co. v. Bell Atl. Corp., 201 F. Supp. 2d 123 (D.D.C. 2002); Cavalier Tel., L.L.C. v. Verizon Va. Inc., 208 F. Supp. 2d 608 (E.D. Va. 2002); Covad Communications Co. v. BellSouth Corp., No. 1:00-CV-3414, slip op. (N.D. Ga. July 6, 2001), rev'd, 299 F.3d 1272 (11th Cir. 2002); Supra Telecomms. \& Info. Sys., Inc. v. 
span the country. Potential competitors in local telephone services sued BellSouth, Verizon, and Pacific Bell in Florida, Virginia, and California, respectively. A provider of high speed Internet access sued BellSouth and Bell Atlantic in Georgia and the District of Columbia. And telephone service consumers filed class actions against Ameritech and Bell Atlantic in Chicago and New York. The allegations in each case are essentially identical, that the ILECs were complying with the 1996 Act, if at all, in the most grudging way possible in order to stifle competition. Some of the complaints highlight that this conduct violates the Act, ${ }^{35}$ while others focus on more traditional antitrust theories ${ }^{36}$ - the refusal to deal ${ }^{37}$ and the essential facilities ${ }^{38}$ doctrines - but at root, all of the cases advanced essentially the same monopoly maintenance claim.

BellSouth Telecomms., Inc., No. 99-1706-CIV-SEITZ, 2001 U.S. Dist. LEXIS 23816 (S.D. Fla. June 8, 2001); MGC Communications, Inc. v. BellSouth Telecomms., Inc., 146 F. Supp. 2d 1344 (S.D. Fla. 2001); Intermedia Communications, Inc. v. BellSouth Telecomms., Inc., 173 F. Supp. 2d 1282 (M.D. Fla. 2000); Law Offices of Curtis V. Trinko, L.L.P. v. Bell Atl. Corp., 123 F. Supp. $2 d 738$ (S.D.N.Y. 2000), aff'd in part, vacated in part, 305 F.3d 89 (2d Cir. 2002), cert. granted, 123 S. Ct. 1480 (2003) (limited to the question: "Did the Court of Appeals err in reversing the District Court's dismissal of respondent's antitrust claims?"); Goldwasser v. Ameritech Corp., No. 97-C6788, 1998 WL 60878 (N.D. Ill. Feb. 4, 1998) (dismissing the consumer class action complaint), aff'd on other grounds, 222 F.3d 390 (7th Cir. 2000). In other cases, courts refused to dismiss antitrust claims based on violations of the Act. Covad Communications Co. v. BellSouth Corp., 299 F.3d 1272 (11th Cir. 2002); Law Offices of Curtis V. Trinko, L.L.P. v. Bell Atl. Corp., 294 F.3d 307, 311 (2d Cir. 2002) (consumer case reserving judgment on competitor claims); Davis v. Pac. Bell, $204 \mathrm{~F}$. Supp. 2d 1236, 1242 (N.D. Cal. 2002) (agreeing with Goldwasser and its progeny that "a violation of the Telecommunications Act 'does not automatically equate to a violation of the Sherman Act," but holding "that an allegation that a defendant violated the Telecommunications Act in a 'predatory' manner as defined in Aspen Skiing states a cause of action under the Sherman Act"); Stein v. Pac. Bell Tel. Co., 173 F. Supp. 2d 975, 985-86 (N.D. Cal. 2001) (same, but dismissing with leave to amend because the claim, as alleged, failed to attribute damages to the plausible antitrust claim); Electronet Intermedia Consulting, Inc. v. Sprint-Fla., Inc., No. 4:00-CV-0176-RH (N.D. Fla. Sept. 20, 2000).

35. See, e.g., Goldwasser, 222 F.3d at 394-95; Supra Telecomms. \& Info. Sys., 2001 U.S. Dist. LEXIS 23816, at *9, *14.

36. See, e.g., Cavalier Tel., 208 F. Supp. $2 \mathrm{~d}$ at 611 . The court explained that while the plaintiff "avoids such tell-tale references [to the 1996 Act] in its Complaint, it is nevertheless clear that [it] alleges nothing more than violations of duties imposed on Verizon by the 1996 Act." Id. at 613. That the plaintiff "did not characterize its allegations as violations of the 1996 Act," the court explained, was "beside the point. Such a shallow interpretation of the relationship between the 1996 Act and antitrust law would relegate the matter to a mindless word game played out at the pleading stage .... The correct test is whether the factual allegations contained in the Complaint amount to antitrust violations." Id.

37. See Aspen Skiing Co. v. Aspen Highlands Skiing Corp., 472 U.S. 585, 601 (1985).

38. See MCI Communications Corp. v. Am. Tel. \& Tel. Co., 708 F.2d 1081, 1132-33 (7th Cir. 1983). 
Covad Communications' allegations against BellSouth are illustrative. The 1996 Act required the ILECs to make space available on their premises as necessary for interconnection, a requirement known as collocation. $^{39}$ While BellSouth entered interconnection agreements with Covad, the new competitor accused BellSouth, inter alia, of: (1) "regularly misrepresent[ing] the availability of space," (2) "severely delay[ing] Covad's application for collocation by months," and (3) "strategically understaffing its wholesale divisions and refusing to develop electronic systems for placing orders." 40 As a result of these alleged improprieties, Covad claimed that BellSouth had intentionally "thwarted Covad's aggressive first-to-market strategy, caused [it] to lose customers, and devastated [its] ability to deliver high quality service" in competition with BellSouth. ${ }^{41}$

In an unregulated market, these claims would state a cause of action under section 2 of the Sherman Act. The plaintiffs alleged both elements of a section 2 claim - that the defendants had (1) monopoly power in the relevant market for local telephone service and (2) engaged in predatory acts - acts intended to exclude competition with no procompetitive purpose or legitimate business justification. ${ }^{42}$ The question for the courts is whether the existence of the 1996 Act alters that conclusion. The Second and Eleventh Circuits and the enforcement agencies have said no. But the Seventh Circuit and a majority of district courts have dismissed these antitrust claims on the pleadings.

39. 47 U.S.C. $\S 251(c)(6)(2000)$.

40. Covad Communications Co. v. BellSouth Corp., No. 1:00-CV-3414, slip op. at 4 (N.D. Ga. July 6, 2001); see also Law Offices of Curtis V. Trinko, L.L.P. v. Bell Atl. Corp., 305 F.3d 89, 95 (2d Cir. 2002) (where the plaintiff alleged that Bell Atlantic discriminated in favor of its own customers); Cavalier Tel., 208 F. Supp. 2d at 612 (explaining Cavalier's allegations "that Verizon mis-routed Cavalier's calls, . . . supplied Cavalier with an inferior Web interface for use in ordering loops,... and ... intentionally made the billing process for loops costly for its competitors").

41. Covad, No. 1:00-CV-3414 at 4; see also Goldwasser v. Ameritech Corp., 222 F.3d 390, 394-95 (7th Cir. 2000) (alleging that Ameritech engaged in twenty specific exclusionary practices, each of which amounted to a violation of a duty imposed under the 1996 Act); Supra Telecomms. \& Info. Sys., Inc. v. BellSouth Telecomms., Inc., No. 99-1706-CIV-SEITZ, 2001 U.S. Dist. LEXIS 23816, at *9 (S.D. Fla. June 8, 2001) (alleging that BellSouth's refusal to provide access hindered competition with BellSouth directly and also made future competition more difficult by destroying business relationships between Supra and its customers).

42. The elements of a section 2 Sherman Act violation are: (1) the willful acquisition, maintenance, or extension of monopoly power (2) by the use of exclusionary or predatory conduct, "to foreclose competition, to gain a competitive advantage, or to destroy a competitor." United States v. Griffith, 334 U.S. 100, 107 (1948); see Eastman Kodak Co. v. Image Technical Servs., Inc., 504 U.S. 451, 481 (1992). 


\section{THE LAW OF ANTITRUST-REGULATORY ACCOMMODATION AND THE TELECOM-ANTITRUST CASES}

This Part reviews existing antitrust-regulatory accommodation law and explains that the Supreme Court has misleadingly developed two lines of doctrine: (1) implied immunity, which is said to focus on conflict, and (2) antitrust state action, which looks to government supervision. ${ }^{43}$ In fact, the Supreme Court cases turn on the presence of official oversight of anticompetitive conduct allegedly serving the noncompetition public policy goals of industry-specific regulatory statutes. Conflict, as that term is normally understood, is not a critical factor. After reviewing the Supreme Court cases, this Part shows that the Second and Eleventh Circuits have mistakenly relied on the absence of conflict, while the Seventh Circuit has, perhaps unconsciously, relied on the presence of supervision. As Part IV explains, this doctrine was developed to accommodate antitrust and regulation that serves a goal other than competition. Neither approach is adequate where regulation, like the Telecom Act, is intended to enhance competition.

\section{A. The Existing Law of Antitrust-Regulatory Accommodation}

Historically, the courts have employed two different lines of authority to determine the impact of industry-specific regulation on the antitrust laws. Particularly in cases of federal regulation, the courts have employed the implied immunity doctrine, which holds that a conflict between a regulatory scheme and the Sherman Act will block antitrust scrutiny of

43. A third approach to antitrust-regulatory accommodation is known as the Keogh or filed rate doctrine. It holds that a private treble damage action will not lie when the plaintiff attacks a rate that has been filed and approved by a regulatory body even if the rate was collusively set, and the plaintiff proves that it would have been lower absent the collusion. See Keogh v. Chi. \& N.W. Ry. Co., 260 U.S. 156, 160-62 (1922). While some of the telecom-antitrust cases have mentioned this doctrine, for example, Goldwasser, 222 F.3d at 402, it has no relevance to the argument advanced here. The Keogh doctrine does not alter the antitrust duties imposed on regulated entities; it merely insulates them from treble damage liability, leaving antitrust duties in place and enforceable through criminal or injunctive actions. Square D Co. v. Niagara Frontier Tariff Bureau, Inc., 476 U.S. 409, 422 \& n.28 (1986) ("Keogh simply held that an award of treble damages is not an available remedy" when a rate is filed with and approved by a regulatory body; a regulated defendant's conduct remains "within the reach of the generally applicable antitrust laws."). 
the defendant's conduct. ${ }^{44}$ In cases of state regulation, the courts have asked whether conduct that would violate the antitrust laws furthers private interests or the state's regulatory vision. This doctrine, known as antitrust state action, holds that conduct that is (1) undertaken pursuant to a state policy to displace competition with regulation and (2) actively supervised by governmental actors will be deemed to serve the state's regulatory vision and will not be scrutinized under the antitrust laws. ${ }^{45}$

While these two lines of authority appear to ask quite different questions, the holdings in the cases turn on a single issue: whether the legislature has provided for sufficient governmental oversight of potentially anticompetitive conduct. Where it has, antitrust scrutiny has been deemed unnecessary.

\section{Implied Immunities Are Disfavored}

Implied antitrust immunities as a result of industry-specific regulation are said to be "strongly disfavored." "The U.S. Supreme Court has explained that the antitrust laws embody a "fundamental national economic policy" in favor of competition. ${ }^{47}$ While Congress may put that policy aside in pursuit of other public policy goals, in the absence of specific language, courts assume that Congress intended to limit antitrust enforcement only to the minimum extent necessary to achieve some alternative public policy goal. ${ }^{48}$

\footnotetext{
44. See infra Part III.A.1.

45. See infra Part III.A.2.

46. See Square D, 476 U.S. at 421 (explaining that "exemptions from the antitrust laws are strictly construed and strongly disfavored").

47. Nat'l Gerimedical Hosp. \& Gerontology Ctr. v. Blue Cross, 452 U.S. 378, 388 (1981) (quoting Carnation Co. v. Pac. Westbound Conference, 383 U.S. 213, 218 (1966)).

48. In National Gerimedical Hospital, the Court summarized the implied
} immunity doctrine as follows:

The antitrust laws represent a fundamental national economic policy. Implied antitrust immunity is not favored, and can be justified only by a convincing showing of clear repugnancy between the antitrust laws and the regulatory system. Repeal is to be regarded as implied only if necessary to make the [subsequent law] work, and even then only to the minimum extent necessary. This is the guiding principle to reconciliation of the two statutory schemes.

$I d$. at 388-89 (alteration in original) (internal quotations and citations omitted); see also Square D, 476 U.S. at 421; United States v. Phila. Nat'l Bank, 374 U.S. 321, 350-51 (1963); Silver v. N.Y. Stock Exch., 373 U.S. 341, 357 (1963); United States v. McKesson \& Robbins, Inc., 351 U.S. 305, 316 (1956).

The Court has employed the implied immunity doctrine to justify the narrow interpretation of regulatory statutes that explicitly state an intent to immunize certain conduct from antitrust attack. See, e.g., Fed. Mar. Comm'n v. Seatrain Lines, Inc., 411 U.S.

726, 733 (1973); Carnation Co. v. Pac. Westbound Conference, 383 U.S. 213, 218 (1966).

We have long recognized that the antitrust laws represent a fundamental national economic policy and have therefore concluded that we cannot lightly assume that the enactment of a special regulatory scheme for particular aspects of an industry was intended to render the more general provisions of the 
For example, in Silver v. New York Stock Exchange, ${ }^{49}$ the plaintiff brought antitrust claims against the Exchange and its members for collectively refusing to provide private communication lines connecting the plaintiff's offices to members of the Exchange. ${ }^{50}$ These lines were alleged to be essential to the firm's ability to compete effectively, ${ }^{51}$ and outside the context of a regulated industry, the Exchange members' concerted refusal to provide the lines to nonmembers would have violated the antitrust laws. ${ }^{52}$

The Exchange argued that its conduct should be exempt because the Securities Exchange Act of 1934 required it to regulate its members. ${ }^{53}$ The Second Circuit agreed because the Exchange's conduct "was within the general scope of the authority of the Exchange as defined by the 1934 Act." ${ }^{\text {" }}$ But the Supreme Court reversed, holding that "a general power to adopt rules" that might have anticompetitive effects does not mean that "particular applications of such rules" will never violate the antitrust laws. ${ }^{55}$ An exemption from antitrust scrutiny could be implied "only if necessary to make the Securities Exchange Act work, and even then only to the minimum extent necessary." ${ }^{\text {"C }}$ After reviewing the application of the rule in the case before it, the Court concluded that the Exchange's conduct was not necessary to make the Exchange Act work, and held that antitrust scrutiny was appropriate. ${ }^{57}$

\section{Regulated Conduct Supervised by Public Actors Falls Outside the Scope of the Antitrust Laws}

Silver is often read to require a search for conflict between the regulatory legislation and the antitrust laws. In fact, however, the presence or absence of a conflict has little to do with the decision whether to apply the antitrust laws to the regulated industry. Indeed, the conflict in Silver could not have been more clear. The rule directly

Id.

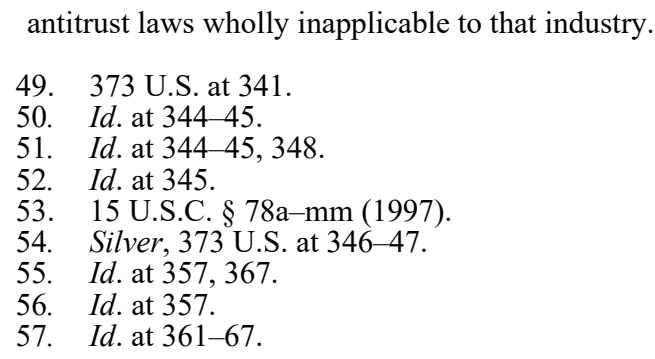


restrained competition that the antitrust laws would otherwise require. The result in Silver was dependent not on the absence of conflict, but on a lack of direct governmental oversight of the challenged conduct. The Securities and Exchange Commission (SEC) had the power to review the Exchange's rules, but not specific applications of those rules. ${ }^{58}$ Given the private genesis of the Exchange's anticompetitive decisions and the lack of governmental oversight, a complete exemption from antitrust scrutiny would have "defeat[ed] the congressional policy reflected in the antitrust laws without serving the policy of the Securities Exchange Act." ${ }^{59}$ But, the Court stressed, if review of Exchange self-regulation were provided by a governmental entity, "a different case as to antitrust exemption would be presented." 60

In Gordon v. New York Stock Exchange, Inc. ${ }^{61}$ the Court encountered that "different case," 62 challenging the Exchange's collective setting of commissions. As in Silver, the regulation (1) granted the Exchange the self-regulatory power necessary to take the challenged action, and (2) contemplated that anticompetitive effects might flow from that action in the process of serving other public policy goals. In contrast to Silver, however, the SEC had the power to oversee rate setting and had actively supervised the process. ${ }^{63}$ As a result, the Court held that the Exchange's

58. Id. at $357-58$.

59. Id. at 360

60. Id.; see also Nat'l Gerimedical Hosp. and Gerontology Ctr. v. Blue Cross, 452 U.S. 378, 389-91 (1981) (explaining that "[i]ntent to repeal the antitrust laws is much clearer when a regulatory agency has been empowered to authorize or require the type of conduct under antitrust challenge"); $c f$. United States v. Phila. Nat'l Bank, 374 U.S. 321 , 351-52 (1963) (applying antitrust laws despite governmental regulation, and explaining that "the range and scope of administrative powers under the Bank Merger Act bear little resemblance to those involved" in a prior case where the antitrust laws were held inapplicable).

61. 422 U.S. 659 (1975)

62. Id. at 685 ("It is patent that the case presently at bar is, indeed, that 'different case' to which the Court in Silver referred.").

63. The Court explained that "[i]n contrast to the circumstances of Silver," the SEC here had "direct regulatory power over" collective rate setting. Id. "Since 1934," the Court observed, "all rate changes have been brought to the attention of the SEC, and it has taken an active role in review of proposed rate changes ...." Id. In distinguishing a lower court securities case that found no immunity, the Court explained that "there was no evidence presented regarding the extent of SEC review of the challenged rule." $I d$. at 686-87. The Court distinguished Philadelphia National Bank on similar grounds: "there was an absence of continuing oversight by the Comptroller General of the Currency." Id. at $689-90$ n.14. Finally, Justice Douglas emphasized the point in his concurring opinion:

The mere existence of a statutory power of review by the SEC over fixed commission rates cannot justify immunizing those rates from antitrust challenges.... Only if the SEC is actively and aggressively exercising its powers of review and approval can we be sure that fixed commission rates are being monitored in the manner which Congress intended.

Id. at 691-92 (Douglas, J., concurring). 
collective rate setting was not subject to antitrust scrutiny. ${ }^{64}$

The federal regulation cases demonstrate that the deciding factor is the degree of government oversight rather than the extent of the conflict between regulatory and antitrust duties. ${ }^{65}$ But what does governmental involvement have to do with accommodating two statutory regimes? The answer rests on an understanding of the nature of antitrust as a mechanism to control privately motivated business decisions, but not governmental conduct. Where public actors oversee regulated conduct, the activity loses its character as privately motivated conduct. Antitrust is therefore inapplicable. ${ }^{66}$

This characterization of antitrust-regulatory accommodation has received more attention in cases and commentary when courts review state regulation. ${ }^{67}$ The Court's 1943 decision in Parker v. Brown ${ }^{68}$ held

64. Id. at 685-86. In United States v. National Ass'n of Securities Dealers, Inc., 422 U.S. 694 (1975), the Court held the antitrust laws inapplicable to certain mutual fund activities. Id. at 733. The Court explained:

There can be little question that the broad regulatory authority conferred upon the SEC by the Maloney and Investment Company Acts enables it to monitor the activities questioned... and the history of Commission regulations suggests no laxity in the exercise of this authority. To the extent that any of appellees' ancillary activities frustrate the SEC's regulatory objectives it has ample authority to eliminate them.

Id. at 734 (footnotes omitted). Similarly, in Hughes Tool Co. v. Trans World Airlines, Inc., 409 U.S. 363 (1973), the Court held regulated conduct outside the scope of antitrust law. Id. at 387. The Court explained:

[W]here, as here, the [governmental body] authorizes control of an air carrier to be acquired by another person or corporation, and where it specifically authorizes as in the public interest specific transactions between the parent and the subsidiary, the way in which that control is exercised in those precise situations is under the surveillance of the [governmental body], not in the Id. at 387 . hands of those who can invoke the sanctions of the antitrust laws.

65. For example, the Court in Square D Co. v. Niagara Frontier Tariff Bureau permitted antitrust attacks on regulated rates that were filed and approved, although it did prohibit the award of damages. 476 U.S. 409, 422 (1986); see also Nat'l Gerimedical Hosp., 452 U.S. at 389 (explaining that "[i]ntent to repeal the antitrust laws is much clearer when a regulatory agency has been empowered to authorize or require the type of conduct under antitrust challenge," and "antitrust repeals are especially disfavored where the antitrust implications of a business decision have not been considered by a governmental entity").

66. See Steven Semeraro, Demystifying Antitrust State Action Doctrine, 24 HARV. J.L. \& PuB. POL'Y 203, 236-39 (2000); Einer Richard Elhauge, The Scope of Antitrust Process, 104 HARV. L. REV. 667, 672, 697-703 (1991).

67. IA AREEDA \& HOVENKAMP, supra note 2, 242d ("Although distinctive in origin, historical justification, and verbal formulation, the rationale for the 'state action' doctrine creating immunity from federal antitrust [review] for state and local government 
that federal law did not preempt a state regulatory program because the Sherman Act was not meant "to restrain state action or official action directed by a state." ${ }^{69}$ The doctrine is governed by a two-part test that asks whether the state (1) "clearly articulated" its intent to displace competition with regulation, and (2) "actively supervised" the private parties in the regulated market. ${ }^{70}$

As applied, the test asks first whether the state has articulated a general intent to displace the forces of the free market with some form of state regulation. ${ }^{71}$ To be considered state action in this context, an anticompetitive byproduct of economic regulation need only be a foreseeable result of a particular statute; it need not be compelled or even necessary to the regulatory scheme. ${ }^{72}$ The so-called clear articulation prong of the test requires a party to point to legislation that has been (or, if not yet interpreted, could reasonably be) read by state courts, agencies, or municipalities to embody the view that the public interest would be served if a regulatory scheme displaced the forces of the free market. The existence of a statute meeting this criterion ensures that the state legislature at least conceived of the possibility that the authorized regulation would have anticompetitive effects.

Read in isolation, the first prong of this test appears to contradict the premise that antitrust immunities are disfavored because it interprets intent to displace competition so liberally. For a private party's conduct to be exempt from antitrust scrutiny, however, it must also be actively supervised by governmental officials in a manner sufficient to ensure that the state's view of the public interest - rather than the private interests of the regulated parties - is served. ${ }^{73}$ "Actual state involvement, not deference to private [anticompetitive] arrangements under the general auspices of state law, is the precondition for [application of the doctrine]." 74 The active supervision requirement ensures that the challenged "anticompetitive acts were truly the product of state regulation." 75

Under this view, antitrust rules limit only the ability of a private

regulation is quite similar to the rationale for an antitrust immunity from federal regulation.").

68. 317 U.S. 341 (1943).

69. Id. at 351 .

70. See S. Motor Carriers Rate Conference, Inc. v. United States, 471 U.S. 48, 57 (1985); Town of Hallie v. City of Eau Claire, 471 U.S. 34, 43-44 (1985); Cal. Retail Liquor Dealers Ass'n v. Midcal Aluminum, Inc., 445 U.S. 97, 105-06 (1980).

71. See Midcal Aluminum, 445 U.S. at 105.

72. See S. Motor Carriers Rate Conference, 471 U.S. at 61; Town of Hallie, 471 U.S. at $41-46$.

73. Fed. Trade Comm'n v. Ticor Title Ins. Co., 504 U.S. 621, 633 (1992); Patrick v. Burget, 486 U.S. 94, 100-01 (1988).

74. Ticor Title Ins., 504 U.S. at 633.

75. Patrick, 486 U.S. at 100. 
business to enter anticompetitive agreements or take actions that tend to create or maintain a monopoly. Antitrust places these limits on private conduct not because agreements and monopolies are inherently undesirable in all contexts. Unrestrained competition also can have negative public welfare effects. ${ }^{76}$ Antitrust doctrine holds only that the forces of competition must prevail over the private decisions of presumptively self-interested business persons because private actors will be tempted to use collusion or monopoly power to serve their own interests. But when a public-interested actor makes the decision to displace free market forces, antitrust principles are not offended because governmental actors may be trusted to choose anticompetitive solutions only when they are in the public interest.

\section{B. Court and Agency Analysis in the Telecom-Antitrust Cases Rests on These Doctrines}

The following Subsections show how the courts deciding the telecomantitrust cases have relied on these two doctrines.

\section{The Second and Eleventh Circuits Rely on the Implied Immunity Doctrine}

In Law Offices of Curtis V. Trinko, L.L.P. v. Bell Atlantic Corp. and Covad Communications Co. v. BellSouth Corp., the lower courts dismissed the antitrust claims on the ground that antitrust does not require a firm, even a monopolist, to help its competitors. ${ }^{77}$ On appeal, the courts correctly recognized that the Sherman Act sometimes does impose positive duties on monopolists. ${ }^{78}$ Because the complaint alleged all the elements of a section 2 case, it could not be dismissed unless the 1996 Act immunized Bell Atlantic from antitrust attack.

The Second and Eleventh Circuits - in keeping with the arguments in

76. Congress has implicitly recognized this by creating explicit antitrust exemptions, silently acquiescing in judicially created exemptions, and granting broad discretion to the courts to shape antitrust duties. Semeraro, supra note 66, at 236-39.

77. Law Offices of Curtis V. Trinko, L.L.P. v. Bell Atl. Corp., 305 F.3d 89, 96 (2d Cir. 2002); Covad Communications Co. v. BellSouth Corp., 299 F.3d 1272, 1278 (11th Cir. 2002).

78. Law Offices of Curtis V. Trinko, 305 F.3d at 108-09 (holding that allegations amounting to violations of the 1996 Act state section 2 claims under the essential facilities and monopoly leveraging doctrines); Covad Communications Co. v. BellSouth Corp., 299 F.3d at 1284-87 (same). 
Antitrust Division and FCC amicus filings in other cases-followed the conflict-centered dicta in the Supreme Court implied immunity cases and held that the Telecom Act did not block antitrust scrutiny. ${ }^{79}$ Because the Telecom Act's express purpose is to engender just the sort of competition that the antitrust laws are designed to preserve, there is obviously no conflict. ${ }^{80}$ The Second Circuit explained that such a conclusion is "unambiguously" established by the Act's antitrust savings clause. $^{81}$ Neither the courts nor the agencies consider the effect of

79. Law Offices of Curtis V. Trinko, 305 F.3d at 109; see Covad Communications Co. v. BellSouth Corp., 299 F.3d at 1280; see also Brief of Amici Curiae United States and the Federal Communications Commission as Amici Curiae at 10, Covad Communications Co. v. BellSouth Corp., 299 F.3d 1272 (No. 01-16064-C); Brief for the United States and Federal Communications Commission as Amici Curiae in Support of Appellants at 8, Intermedia Communications, Inc. v. BellSouth Telecomms., Inc. (11th Cir. filed Jan. 12, 2001) (No. 01-10224-JJ).

80. Law Offices of Curtis V. Trinko, 305 F.3d at 109; Covad Communications Co. v. BellSouth Corp., 299 F.3d at 1281-82 (supporting conclusion with references to legislative history and presidential and FCC statements); Brief of Amici Curiae United States and the Federal Communications Commission as Amici Curiae at 14-15, Covad Communications Co. v. BellSouth Corp., 299 F.3d 1272 (No. 01-16064-C) (contrasting the Telecom Act with a statute that empowers "a regulatory agency ... to approve, in furtherance of other regulatory goals, anticompetitive conduct that would otherwise violate the antitrust laws"); Brief for the United States and Federal Communications Commission as Amici Curiae in Support of Appellants at 10-12, Intermedia Communications (No. 01-10224-JJ).

81. Law Offices of Curtis V. Trinko, 305 F.3d at 109. The 1996 Act actually contains two savings clauses: (1) "nothing in this Act or the amendments made by this Act shall be construed to modify, impair, or supersede the applicability of any of the antitrust laws," Pub. L. No. 104-104, § 601, Stat. 143 (1996); and (2) "This Act and the amendments made by this Act shall not be construed to modify, impair, or supersede Federal, State, or local law unless expressly so provided in such Act or amendments." 47 U.S.C. § 152(c)(1) (2000). The legislative history of the Act also supports this understanding by recognizing as an "underlying theme" of the Act that the FCC "should be carrying out the policies of the Communications Act, and the DOJ should be carrying out the policies of the antitrust laws." H.R. CONF. REP. No. 104-458, at 201 (1996). The House Conference Report also confirmed that the Act's savings clauses "[prevent] affected parties from asserting that the [Act] impliedly preempts other laws." Id.

While generally in accord with the Second Circuit's decision in Trinko, amicus briefs filed by the enforcement agencies rely more heavily on the antitrust savings clause to support their position that full antitrust analysis is required. Brief of Amici Curiae United States and the Federal Communications Commission as Amici Curiae at 10, Covad Communications Co. v. BellSouth Corp., 299 F.3d 1272 (No. 01-16064-C) (explaining that the savings clause meant that "conduct that would have violated the Sherman Act before passage of the 1996 Act is still prohibited by the Sherman Act, whether or not it also violates the 1996 Act"); Brief for the United States v. Federal Communications Commission as Amici Curiae in Support of Appellants at 8, Intermedia Communications (No. 01-10224-JJ) (same). But as Judge Martin explained in her opinion dismissing Covad's case against Bell Atlantic, the clause merely preserves existing antitrust doctrine. If the scope of antitrust does not reach regulated conduct highly supervised by governmental actors, and the 1996 Act meets that definition, then violations of the Act's provisions would not constitute antitrust violations despite the savings clause. Covad Communications Co. v. Bell Atl. Corp., 201 F. Supp. 2d 123, 131 (D.D.C. 2002) ("Congress made explicit its intention that the 1996 Act should not in any 
government oversight. Instead, the courts declared that the relationship between the plaintiffs' allegations and the Telecom Act was simply irrelevant to antitrust analysis. ${ }^{82}$ "If there is no ... implicit immunity," the Second Circuit explained, "as long as a set of allegations states an antitrust action on its own terms, the fact that it closely resembles an action brought under another statute in itself is unproblematic." ${ }^{83}$

\section{The Seventh Circuit and Most Lower Courts Implicitly Rely on Government Oversight}

The following Subsections analyze the much more confusing analysis in Goldwasser v. Ameritech Corp. ${ }^{84}$ and the cases that follow it. These courts explicitly reject any reliance on the implied immunity doctrine. They instead hold that a violation of a duty imposed by the 1996 Act cannot be anticompetitive within the meaning of the Sherman Act. ${ }^{85}$ The final Subsections consider two explanations for this result: (1) that antitrust does not impose positive duties to assist potential competitors, and (2) that conduct actively supervised by governmental actors falls outside the scope of antitrust scrutiny. They conclude that the latter analysis provides the best rationale for the results in these cases. As explained in Part IV, however, existing antitrust-regulatory accommodation doctrine is inadequate where the regulation seeks to enhance competition.

way alter the application or scope of existing antitrust law."); $c f$. Square D Co. v. Niagara Frontier Tariff Bureau, Inc., 476 U.S. 409, 418, 419 \& n.23, 420 \& n.27 (1986) (recognizing that the antitrust savings clause in the Reed-Bulwinkle Act and the Motor Carrier Act preserved antitrust limitations of the filed rate doctrine).

82. Law Offices of Curtis V. Trinko, 305 F.3d at 109 (holding that "there is no requirement that an allegation that otherwise states an antitrust claim must not rely on allegations that might also state a claim under another statute"); see also id. at 111 (holding that "controlling case law does not support the theory that specific legislation meant to encourage competition necessarily takes precedence over the general antitrust laws."); Covad Communications Co. v. BellSouth Corp., 299 F.3d at 1282 ("[W]e cannot agree with Goldwasser to the extent that it is read to say that a Sherman Act antitrust claim cannot be brought as a matter of law on the basis of an allegation of anti-competitive conduct that happens to be 'intertwined' with obligations established by the 1996 Act.").

83. Law Offices of Curtis V. Trinko, 305 F.3d at 109; see also Covad Communications Co. v. BellSouth Corp., 299 F.3d at 1282-83.

84. 222 F.3d 390 (7th Cir. 2000), aff'g on other grounds, No. 97-C-6788, 1998 WL 60878 (N.D. Ill. Feb. 4, 1998).

85. See infra Part III.B.2.a. 


\section{a. The Goldwasser Decision and Its Progeny}

In Goldwasser, the Seventh Circuit upheld the dismissal of an antitrust claim by local telephone service customers against Ameritech. ${ }^{86}$ On its face, the complaint alleged the elements necessary to prove that Ameritech violated section 2 of the Sherman Act. ${ }^{87}$ Local telephone service undoubtedly forms a relevant antitrust market, and Ameritech certainly had monopoly power in that market by virtue of its overwhelming market share and the high barriers to entry into local telephone service. The only real question was whether the alleged conduct constituted anticompetitive predatory conduct or procompetitive conduct justified by a legitimate business justification.

The court never engaged in the analysis necessary to answer that question. ${ }^{88}$ Judge Wood's opinion did not evaluate whether the conduct substantially contributed to maintaining Ameritech's dominant position,

86. Goldwasser, 222 F.3d at 392, 402.

87. In a monopolization case, the court must define the relevant market, determine whether the defendant has monopoly power in that market, and if so, evaluate whether the challenged conduct is predatory or exclusionary-whether its effect was to exclude or limit competition in a way that did not benefit consumers. For an exemplary recent example of this antitrust analysis, see United States v. Microsoft Corp., 253 F.3d 34, 50-78 (D.C. Cir. 2001). In Goldwasser, no one disputed that Ameritech had market power in local telephone service, and the complaint alleged that its conduct violating the Act was predatory, i.e. without a procompetitive purpose and beneficial to the actor only to the extent that it lessened competition on the merits.

88. Some courts have added, in dicta, that antitrust remedies would threaten the elaborate structure of negotiations and regulatory approval created by the 1996 Act. As the Seventh Circuit explained in Goldwasser: "[T]he procedures established under the 1996 Act for achieving competitive markets are [not] compatible with the procedures that would be used to accomplish the same result under the antitrust laws." Goldwasser, 222 F.3d at 401. "The elaborate system of negotiated agreements and enforcement established by the 1996 Act could be brushed aside by any unsatisfied party with the simple act of filing an antitrust action." Id.; see also Supra Telecomms. \& Info. Sys., Inc. v. BellSouth Telecomms., Inc., No. 99-1706-CIV-SEITZ, 2001 U.S. Dist. LEXIS 23816, at*12 (S.D. Fla. June 8, 2001) (same); Covad Communications Co. v. Bell Atl. Corp., 201 F. Supp. 2d 123, 133 (D.D.C. 2002) (noting a "fundamental incompatibility between the remedial schemes established by the antitrust laws and the 1996 Act").

The agencies' amicus filings explain why the remedy concern is overstated. "[A]ny antitrust relief," they point out, "should take account of regulatory policy and decisions in regulatory proceedings .... The need to harmonize enforcement of complementary federal statutes, however, is not a proper basis for dismissing a complaint - especially one seeking only damages - at the pleading state." Brief of Amici Curiae United States and the Federal Communications Commission as Amici Curiae at 15, Covad Communications Co. v. BellSouth Corp., 299 F.3d 1272 (11th Cir. 2002) (No. 01-16064C). In another amicus brief, the Department agreed "that courts should attempt to avoid conflict with regulatory policy in fashioning antitrust injunctions. The speculative possibility that an injunction could ultimately be entered in this case, however, scarcely justifies dismissing a complaint seeking damages and injunctive relief at the pleadings stage." Brief for the United States and Federal Communications Commission as Amici Curiae in Support of Appellants at 19, Intermedia Communications, Inc. v. BellSouth Telecomms., Inc. (11th Cir. filed Jan. 12, 2001) (No. 01-10224-JJ). 
nor did it look to whether the company had legitimate business reasons for its conduct. That failure would have been understandable if the court had held that the 1996 Act immunized Ameritech from antitrust liability. But the court forswore any reliance on the implied immunity doctrine. ${ }^{89}$

Instead, the court declared, without market-specific analysis, that violations of a regulatory statute are not predatory acts under the antitrust laws. ${ }^{90}$ The court concluded that duties imposed by the 1996 Act "are precisely the kinds of affirmative duties to help one's competitors that ... do not exist under the unadorned antitrust laws." "91 Because those duties "go well beyond anything the antitrust laws would mandate on their own," the complaint amounted to an attack on a monopolist for failing to help its competitors and thereby lower prices for consumers. ${ }^{92}$ Because "the antitrust laws do not impose that kind of affirmative duty, even on monopolists," the complaint failed to state a claim. ${ }^{93}$

The plaintiffs countered, and the court did not dispute, that the antitrust laws sometimes do impose positive duties on monopolists to cooperate with competitors. But because all of the allegations were "inextricably linked to the claims under the 1996 Act," 94 the court held that the more specific provisions of the 1996 Act "must take precedence." 95

Despite its broad language, Goldwasser could be read to establish no more than a rule of careful pleading - that merely alleging a violation of a regulatory statute does not suffice to state an antitrust claim. Instead, a plaintiff must allege with more particularity how such a violation affected competition in the relevant market. ${ }^{96}$ In most telecom-antitrust

89. Goldwasser, 222 F.3d at 401 ("Our principal holding is thus not that the 1996 Act confers implied immunity on behavior that would otherwise violate the antitrust law[s].").

90. See id. at 399-400.

91. Id. at 400

92. Id.

93. Id.

94. Id. at 401 .

95. Id.; see also Brief of Amici Curiae United States and the Federal Communications Commission as Amici Curiae at 18, Covad Communications Co. v. BellSouth Corp., 299 F.3d 1272 (11th Cir. 2002) (No. 01-16064-C).

The meaning of this passage is unclear, particularly in view of the Seventh Circuit's express disclaimer of any holding "that the 1996 Act confers implied immunity on behavior that would otherwise violate the antitrust law," and its acknowledgment that "[s]uch a conclusion would be troublesome at best given the antitrust savings clause in the statute."

Id. (alteration in original) (quoting Goldwasser, $222 \mathrm{~F} .3 \mathrm{~d}$ at 401).

96. Philip J. Weiser, Goldwasser, The Telecom Act, and Reflections on Antitrust Remedies, 55 AdmIn. L. REV. 1 (2003). 
cases following Goldwasser, however, the district courts have interpreted the Seventh Circuit's opinion broadly to preclude any antitrust claim relating to a violation of the 1996 Act irrespective of the specificity of the pleading. ${ }^{97}$ For example, Judge Seitz, in Supra Telecommunications \& Information Systems, Inc. v. BellSouth Telecommunications, Inc., declared that claims of this sort "extend far beyond the purview of [the] antitrust laws which generally do not require a monopolist to 'cooperate with competitors." "98 Similarly, in Covad's case against Bell Atlantic, Judge Kessler wrote that the Act "was designed by Congress to spur competition in local telephone markets in ways that the antitrust laws did not require." 99 As a result, an ILEC's "failure to comply with [the duties imposed by the 1996 Act] . . . does not constitute 'exclusionary' conduct as a matter of law." 100 Following this reasoning, these courts have dismissed all claims bearing any connection to the 1996 Act without evaluating the conduct under the "rule of reason."101

97. For example, in Cavalier, the plaintiff took great care to allege its antitrust claims in the traditional way without reference to the 1996 Act. Cavalier Tel., L.L.C. v. Verizon Va. Inc., 208 F. Supp. 2d 608, 611-12 (E.D. Va. 2002). In dismissing the claims, the court rejected the notion that Goldwasser could be limited to a pleading requirement. Id. at 613 ("That Cavalier's Complaint did not characterize its allegations as violations of the 1996 Act is beside the point. Such a shallow interpretation of the relationship between the 1996 Act and antitrust law would relegate the matter to a mindless word game played out at the pleading stage ....").

98. Supra Telecomms. \& Info. Sys., Inc. v. BellSouth Telecomms., Inc., No. 991706-CIV-SEITZ, 2001 U.S. Dist. LEXIS 23816, at *11 (S.D. Fla. June 8, 2001). "No court has yet held that antitrust laws now include the affirmative duties created by the TCA and this Court shall decline to do so as well." Id. at *14; see also Cavalier Tel., 208 F. Supp. 2d at 613 (explaining that the "specific obligations" imposed by the 1996 Act "extend far beyond the general admonitions against monopolization and anticompetitive behavior expressed by federal antitrust law"); Law Offices of Curtis V. Trinko, L.L.P. v. Bell Atl. Corp., 123 F. Supp. 2d 738, 742 (S.D.N.Y. 2000), aff'd in part, vacated in part, 305 F.3d 89 (2d Cir. 2002).

The affirmative duties imposed by the Telecommunications Act are not coterminous with the duty of a monopolist to refrain from exclusionary practices. Moreover, the mere fact that a monopolist has violated another statute does not transform such offense into a violation of the antitrust laws. Thus, plaintiff has failed to allege any "willful acquisition or maintenance" of monopoly power by Bell Atlantic.

Id. (citations omitted); Law Offices of Curtis V. Trinko, L.L.P. v. Bell Atl. Corp., No. 00-CIV-1910, slip op. at 6 (S.D.N.Y. Apr. 26, 2001) ("Because [plaintiffs have] failed to allege any anticompetitive conduct on the part of Bell Atlantic, its Sherman Act claim must be dismissed.")), rev'd, 305 F.3d 89 (2d Cir. 2002); MGC Communications, Inc. v. BellSouth Telecomms., Inc., 146 F. Supp. 2d 1344, 1351-52 (S.D. Fla. 2001) (quoting extensively from Goldwasser and applying its reasoning).

99. Covad Communications Co. v. Bell Atl. Corp., 201 F. Supp. 2d 123, 130 (D.D.C. 2002).

100. Id.

101. For example, courts have dismissed claims that "raise[d] a duty or obligation created and imposed by the 1996 Act," were "intertwined with," "related to," "included under," "implicated by," “inextricably linked' to," or "essentially a reincarnation of" a 


\section{b. Interpreting Goldwasser and Its Progeny}

This Subsection considers two possible explanations for the results in the Goldwasser line of cases: (1) that violations of the positive duties under the Act could not be anticompetitive in any context, and (2) that active government oversight renders conduct within the market regulated by the 1996 Act beyond the scope of the antitrust laws. This Subsection concludes that while the first explanation is unsupportable, the second provides the best, though still inadequate, justification for the holdings.

\section{i. The Fully Contextual Nature of Antitrust Analysis}

Opinions in the telecom-antitrust cases appear to hold that conduct violating the antitrust laws has certain metes and bounds irrespective of competitive conditions. These lines of demarcation separate collusive conduct and unilateral acts that hinder a competitor's ability to compete from cooperative behavior that assists competitors. The 1996 Act's positive duties to cooperate, the courts seem to believe, fall outside the purview of the antitrust laws in every imaginable context. ${ }^{102}$

Goldwasser surely relied, at least in part, on this line of reasoning. The court emphasized that even monopolists must have sufficient breathing room to compete, and that "[p]art of competing like everyone else is the ability to make decisions about with whom and on what terms one will deal." 103 As a result, "even a firm with significant market

duty created by the 1996 Act. Brief of Amici Curiae United States and the Federal Communications Commission as Amici Curiae at 11, Covad Communications Co. v. BellSouth Corp., 299 F.3d 1272 (11th Cir. 2002) (No. 01-16064-C) (quoting various formulations used in Covad Communications Co. v. Bell Atlantic Corp.); see also Bldg. Communications, Inc. v. Ameritech Servs., Inc., No. 97-CV-76336, slip op. at 20-24 (E.D. Mich. June 21, 2001); Cavalier Tel., 208 F. Supp. 2d at 615 n.3, 616-17 (dismissing the claim based on an "allegation that Verizon employees contacted Cavalier's existing and potential customers in an attempt to draw business away from Cavalier," an allegation that the court admitted "does not concern a duty imposed by the 1996 Act").

102. Covad Communications Co. v. Bell Atl. Corp., 201 F. Supp. 2d at 131 ("[T]here is nearly unanimous consensus that the 1996 Act imposes affirmative duties of assistance that require far more than the existing antitrust laws now require."); $c f$. USM Corp. v. SPS Techs., Inc., 694 F.2d 505, 513 (7th Cir. 1982) ("There is a difference between positive and negative duties, and the antitrust laws, like other legal doctrines sounding in tort, have generally been understood to impose only the latter."). For cases describing the minimum criteria for antitrust liability see Monsanto Co. v. Spray-Rite Service Corp., 465 U.S. 752, 761 (1984); Olympia Equipment Leasing Co. v. Western Union Telegraph Co., 797 F.2d 370, 375 (7th Cir. 1986).

103. Goldwasser v. Ameritech Corp., 222 F.3d 390, 397 (7th Cir. 2000). 
power" has the freedom to deal with customers and partners of its own choosing, unless its "decisions are part of a broader effort to maintain its monopoly power." 104

Many of the lower courts simply follow Goldwasser. But Judge Kessler's opinion in Covad's case against Bell Atlantic expanded on Judge Wood's analysis. She wrote that "conduct that was proscribed prior to the 1996 Act remains proscribed after its enactment. Similarly, conduct that did not violate antitrust law prior to the 1996 Act does not now violate antitrust law after the Act." 105 This language could be interpreted in two ways. Judge Kessler could be making a contextual claim that given the competitive conditions in the local telephone market, the challenged acts do not cause competitive concern irrespective of the 1996 Act. But such a claim would require careful economic analysis not found in the opinion. Judge Kessler does cite the "nearly unanimous consensus that the 1996 Act imposes affirmative duties of assistance that require far more than the existing antitrust laws now require."106 But none of the cited cases engaged in the market specific analysis needed to support that holding.

The utter absence of antitrust analysis suggests a second interpretation of Judge Kessler's language, namely that some conduct, particularly conduct involving a refusal to cooperate with a potential competitor, may never rise to the level of an antitrust violation. But such a noncontextual reading of the antitrust laws conflicts with a longstanding tradition of imposing positive obligations in certain limited contexts where defendants have monopoly power. The traditional starting points are United States v. Terminal Railroad Association, where the U.S. Supreme Court ordered access on fair and equal terms to a jointly-owned bridge across the Mississippi, ${ }^{107}$ and Associated Press v. United States, where the Court required that a cooperative newsgathering agency be opened to the competitors of its existing members. ${ }^{108}$ In Lorain Journal Co. v. United States, the Court compelled a newspaper to accept advertising from firms that also advertised with a competing radio station. ${ }^{109}$ In Aspen Skiing Co. v. Aspen Highlands Skiing Corp., the Court required a ski mountain operator to cooperate with a competitor by selling

104. Id. at 398 .

105. Covad Communications Co. v. Bell Atl. Corp., 201 F. Supp. 2d at 131. Judge Kessler further explained that Covad's "allegations focus on disputes over the terms for obtaining access to Bell Atlantic's local exchange network - an entitlement that was first created by the 1996 Act (not by the antitrust laws)." Id. at 132 .

106. Id. at 131.

107. United States v. Terminal R.R. Ass'n, 224 U.S. 383, 411-12 (1912).

108. Associated Press v. United States, 326 U.S. 1, 21 (1945).

109. Lorain Journal Co. v. United States, 342 U.S. 143, 152-53 (1951). 
tickets that allowed skiers to choose to ski on any mountain. ${ }^{110}$ And the Microsoft case will certainly yield cooperative remedies, most likely in the form of a duty to disclose information about updates in Windows, to allow competitive software providers to update their own products. ${ }^{11}$

These cases demonstrate that antitrust doctrine is contextual. That is, whether particular conduct violates the law depends on the competitive conditions within which the conduct is taken. ${ }^{112}$ Those telecom-antitrust courts that do not ignore this line of authority distinguish it on the ground that the defendants in those cases were not subjected to a regulatory program with as much structure as the program created by the Telecom Act. ${ }^{13}$ They recognize that the U.S. Supreme Court imposed a positive duty on a highly regulated electric utility in Otter Tail Power Co.

110. Aspen Skiing Co. v. Aspen Highlands Skiing Corp., 472 U.S. 585, 598-99 (1985).

111. Revised Proposed Final Judgment in United States v. Microsoft (D.D.C. Nov. 2, 2001), available at http://www.usdoj.gov/atr/cases/f9500/9505.htm.

112. For example, an exclusive dealing arrangement between a new manufacturer and a distributor in a market in which many manufacturers and distributors compete is virtually certain to be a procompetitive way for the new manufacturer to enter the market. Conversely, exclusive dealing arrangements between a dominant manufacturer and the only three effective existing distributors of a particular product causes competitive concern if the smaller competing manufacturers do not have meaningful alternatives for distributing their products.

Antitrust doctrine does include certain per se rules that purport to prohibit particular types of behavior. But even these rules apply contextually. And the courts have been extremely reluctant to adopt rules of per se legality. See Brooke Group Ltd. v. Brown \& Williamson Tobacco Corp., 509 U.S. 209, 229-30 (1993) (rejecting a rule of per se legality for primary-line price discrimination claims where recoupment is premised on oligopoly pricing); Cargill, Inc. v. Monfort of Colo., Inc., 479 U.S. 104, 121 (1986) (rejecting a rule of per se legality for predatory pricing claims arising from a merger). Per se rules against tying and group boycotts explicitly require contextual analysis in the rule itself. See N.W. Wholesale Stationers, Inc. v. Pac. Stationery \& Printing Co., 472 U.S. 284, 293-98 (1985); Jefferson Parish Hosp. v. Hyde, 466 U.S. 2, 9-16 (1984). And even the rules against price fixing, market division, and customer allocation, which are typically stated more matter-of-factly, require some contextual analysis. See Nat'l Collegiate Athletic Ass'n v. Bd. of Regents of the Univ. of Okla., 468 U.S. 85, 104 n.26 (1984); Broad. Music, Inc. v. Columbia Broad. Sys., Inc., 441 U.S. 1, 8-9 (1979).

113. See Cavalier Tel., L.L.C. v. Verizon Va. Inc., 208 F. Supp. 2d 608, 616 n.4 (E.D. Va. 2002) (distinguishing Aspen Skiing on the ground that "Cavalier's allegations concern the manner in which Verizon is meeting its responsibilities under the 1996 Act"); see also Goldwasser v. Ameritech Corp., 222 F.3d 390, 399-400 (7th Cir. 2000) (explaining that Congress could have imposed "passive restrictions on the ILECs, under which they would have been permitted to compete, but they would have been prohibited from engaging in affirmatively exclusionary acts like the efforts of the Ski Company in Aspen Skiing, or the newspaper company in Lorain Journal," but instead Congress chose a more intrusive regulatory approach). 
v. United States, ${ }^{114}$ and the MFJ dismantled AT\&T's regulated monopoly over telephone service. But Judge Kessler maintains that those cases did not involve regulation as pervasive as that imposed by the 1996 Act over the very acts that are alleged to give rise to antitrust liability. ${ }^{115}$

This reasoning goes too far. To be sure, regulation necessarily affects antitrust analysis to the extent that it alters the competitive conditions in the market. ${ }^{116}$ For example, in Town of Concord v. Boston Edison Co., then-Judge Breyer explained that a price squeeze is much less likely to have anticompetitive effects in a market with full price regulation than in an unregulated market. ${ }^{117}$ That conclusion is correct in part because recognizing an antitrust price-squeeze claim in a regulated market would create a perverse incentive for a regulated entity to increase its price at both the wholesale and retail levels whenever it needed to raise price at one level. ${ }^{118}$ Where economic analysis reveals such an anticompetitive

114. Otter Tail Power Co. v. United States, 410 U.S. 366, 375-76 (1973) (requiring a regulated, natural monopoly provider of electric power transmission to cooperate with a competitor at the distribution level).

115. The Federal Power Commission did not have the authority to order the wheeling sought in Otter Tail Power and, while the FCC did have the power to order the interconnection sought in the MCI and government cases brought against AT\&T, the initial interconnection decision rested with the utility and "the FCC [had not] supervised AT\&T's interconnection practices so closely." Covad Communications Co. v. Bell Atl. Corp., 201 F. Supp. 2d 123, 133 \& n.21 (D.D.C. 2002) (quoting MCI Communications Corp. v. Am. Tel. \& Tel. Co., 708 F.2d 1081, 1103 (7th Cir. 1983)).

116. Town of Concord v. Boston Edison Co., 915 F.2d 17, 22 (1st Cir. 1990) (explaining that "where regulatory and antitrust regimes coexist,.... antitrust analysis must sensitively 'recognize and reflect the distinctive economic and legal setting' of the regulated industry to which it applies") (citations omitted) (quoting Keith S. Watson \& Thomas W. Brunner, Monopolization by Regulated "Monopolies": The Search for Substantive Standards, 22 ANTITRUST BULL. 559, 565 (1977)); MCI Communications Corp. v. Am. Tel. \& Tel. Co., 708 F.2d 1081, 1106 (7th Cir. 1983) (explaining that "the presence of a substantial degree of regulation, although not sufficient to confer antitrust immunity, may affect both the shape of 'monopoly power' and the precise dimensions of the 'willful acquisition or maintenance' of that power" (quoting Keith S. Watson \& Thomas W. Brunner, Monopolization by Regulated "Monopolies": The Search for Substantive Standards, 22 ANTITRUST BulL. 559, 563 (1977))); id. at 1109-10 (explaining that a regulated firm should be able to defend against a predatory act charge by showing that it acted in the good faith belief that its actions were required by applicable regulation); Phonetele, Inc. v. Am. Tel. \& Tel. Co., 664 F.2d 716, 737-38 (9th Cir. 1981) (holding that a defendant's "reasonable basis to conclude that its actions were necessitated by concrete factual imperatives recognized as legitimate by the regulatory authority" prevents antitrust liability); IA AREEDA \& HovENKAMP, supra note 2, I 240c3 (explaining that "antitrust courts can and do consider the particular circumstances of an industry and therefore adjust their usual rules to the existence, extent, and nature of regulation").

117. Town of Concord, 915 F.2d at 29. A price squeeze occurs when a producer that also competes at a downstream level leaves too little spread between its wholesale and retail price, threatening to drive downstream firms from the market. See United States v. Aluminum Co. of Am., 148 F.2d 416, 437-38 (2d Cir. 1945).

118. Similarly, a regulated firm would be reluctant to reduce price at one level unless it was prepared to reduce its prices at both. Town of Concord, 915 F.2d at 27. 
effect from recognizing a particular antitrust claim, a court should ordinarily dismiss the claim. ${ }^{119}$

Nothing approaching that sort of analysis can be found in any of the telecom-antitrust cases. They instead rely on the unsupportable assertion that a pervasively regulated firm simply cannot harm competition. As Judge Kessler put it, an ILEC "has no freedom to take any unilateral action relating to access to interconnection with the local networks." 120 Of course, AT\&T made essentially the same argument in the early 1980 s. ${ }^{121}$ It was rejected then because Judge Greene recognized that no matter how extensive regulation might be, it can never pervasively dictate a firm's behavior. ${ }^{122}$ There will always be space within the regulatory rules for a business entity to make significant competitive decisions that are not dictated by regulators. Indeed, business entities quickly learn to play the regulatory rules to minimize their procompetitive impact. ${ }^{123}$ In the telecom-antitrust cases, the ILECs are charged with

119. For example, in Town of Concord, then-Judge Breyer was careful to limit the scope of his holding to circumstances where the court's analysis applied most strongly. He explained that the court:

limited [its] holding by stating that "normally" a price squeeze will not constitute an exclusionary practice in the context of a fully regulated monopoly, thereby leaving cases involving exceptional circumstances for another day. And we have stressed that our reasoning applies with full force only when the monopolist who engages in the squeeze is regulated at both Id. at 29 . industry levels.

120. Covad Communications Co. v. Bell Atl. Corp., 201 F. Supp. 2 d at 133.

121. See United States v. Am. Tel. \& Tel. Co., 524 F. Supp. 1336, 1357-58 (D.D.C. 1981).

122. Id. For this reason, antitrust law has always had "a substantial role in regulated industries." IA AREEDA \& HOVENKAMP, supra note 2, ๆ $241 \mathrm{c}$.

123. See Mark Kelman, A Guide to Critical Legal Studies 27-28, 40-42 (1987) (explaining how entities subject to a set of rules learn to "walk the line" along rules to serve their own interests); see also FREDERICK SCHAUER, PLAYING BY THE RULES: A Philosophical Examination OF RUle-Based DeCision-MaKing In LAW AND IN Life 32-33 (1991) (stating that "[f]actual predicates will therefore in some cases turn on features of the case that do not serve the rule's justification, and in others fail to recognize features of the case whose recognition would serve the rule's justification"). Further, "[t]hese errors are not a function of mistakes that decision-makers may make, but instead are generated by decision-makers faithfully and accurately following the rules." Id. at 49 . "This under- and over-inclusiveness ... is largely ineliminable, the product of entrenchment and not simply of how specific or how general a rule happens to be." Id . at 50. "But rules achieve clarity, certainty, and determinateness, at the price of including either more or fewer cases in the legal categories defined by the rules than the rationale underlying the rule calls for." $I d$. at 50 n.14 (quoting GERALD J. POSTEMA, BENTHAM AND THE COMMON LAW TRADITION 447 (1986)).

Congress surely foresaw that problem in the local telephone service market and 
doing exactly that: delaying, discriminating, and engaging in other anticompetitive conduct that has not been prevented by-and certainly was not required by-the regulatory scheme. ${ }^{124}$

\section{ii. Regulation and Government Supervision}

Although the results in Goldwasser and its progeny would be inexplicable in an unregulated market, the opinions in those cases emphasize the importance of regulation. From the perspective of the implied immunity doctrine, as traditionally understood, these references to regulation appear to be irrelevant. There is simply no conflict between the statutes. But if one views the opinions through the prism of the antitrust state action doctrine, a more coherent approach emerges. In Goldwasser, Judge Wood explained that competitors should rely on the "elaborate enforcement structure that Congress created [in the 1996 Act] for purposes of managing the transition from the former regulated world to the hoped-for competitive markets of the future." 125 Perhaps if those mechanisms were wholly ineffectual, antitrust might have some role to play. Because "[q]uestions concerning the duties of the ILECs, the state commissions, and competitors have been coming before the courts with regularity," she concluded, "[t]he antitrust laws would add nothing to the oversight already available under the 1996 law."126

Judge Kessler's opinion in Covad v. Bell Atlantic also emphasized that private conduct cannot be anticompetitive if it is actively supervised by public-minded government regulators. In rejecting Covad's argument that Bell Atlantic had denied it access to an essential facility, Judge Kessler maintained that:

there can be no significant harm to competition or anti-competitive effect as a matter of antitrust law, as every relevant facet of Bell Atlantic's relationship with Covad is subject to regulation under the 1996 Act, the rules of the FCC, and the affirmative and active supervision of state public utility commissions charged with the 1996 Act's enforcement. ${ }^{127}$

responded by requiring negotiated agreements between competitors rather than proscribing the specific terms on which they had to deal. Law Offices of Curtis V. Trinko, L.L.P. v. Bell Atl. Corp., 305 F.3d 89, 104 (2d Cir. 2002) ("Congress sought to allow ILECs and their competitors to govern their interconnection relationships directly through specific interconnection agreements rather than the broadly outlined duties described in [section 251].").

124. As the Second Circuit explained: "While ideally, the regulatory process alone would be enough to bring competition to the local phone service markets, it is possible that the antitrust laws will be needed to supplement the regulatory scheme...." Law Offices of Curtis V. Trinko, 305 F.3d at 112 (footnote omitted).

125. Goldwasser v. Ameritech Corp., 222 F.3d 390, 400 (7th Cir. 2000).

126. Id. at $400-01$.

127. Covad Communications Co. v. Bell Atl. Corp., 201 F. Supp. 2d 123, 132 
This is not an argument about conflicting statutory schemes. It is an assertion of substantive antitrust law-that antitrust law does not function where regulation rather than marketplace forces govern competitive interaction among firms. This assertion is the antitrust state action doctrine: private conduct falls outside the scope of antitrust scrutiny because it is the product of public, rather than private, decision.

By finding that the challenged conduct falls outside the scope of antitrust law, these decisions avoid running afoul of the Telecom Act's antitrust savings clause. As Judge Kessler explained, the savings clause merely preserves existing antitrust doctrine. ${ }^{128}$ But existing doctrine includes doctrine that defines limitations on the scope of antitrust. Conduct that violated the antitrust laws before the enactment of the 1996 Act - private business conduct - would continue to violate the antitrust laws. But conduct subject to active oversight by state actors, which did not violate the antitrust laws before the 1996 Act, could not become an antitrust violation as a result of the Act.

A likely objection to this interpretation of the Goldwasser line of cases is that antitrust state action applies only to state regulation, and the Telecom Act is obviously federal law. As described above, however, the U.S. Supreme Court has looked to supervision by governmental actors regardless of the source of the regulation. And, in similar cases involving joint federal-state regulation of electric and gas utilities, the courts have had no difficulty applying antitrust state action doctrine.

For example, electric utilities, like telephone companies, have long been subjected to a dual system of regulation. In 1978, Congress passed the Public Utility Regulatory Practices Act (PURPA), ${ }^{129}$ defining a class of small scale electric power generators that could reduce the monopoly local electricity providers' reliance on fossil fuel. ${ }^{130}$ Congress recognized two barriers to this sort of entry into electric power generation that were remarkably similar to the difficulties faced in the local telephone service market. First, existing regulatory structures made market entry cumbersome and expensive. ${ }^{131}$ Second, the utilities had no incentive to agree to provide

(D.D.C. 2002) ("Bell Atlantic has no freedom to take any unilateral action relating to access to interconnection with the local networks.")

128. See id. at $130-31$.

129. 16 U.S.C. $\$ 824(1994)$

130. Id. § 796(17)(A)-(18)(B).

131. TEC Cogeneration Inc. v. Fla. Power \& Light Co., 76 F.3d 1560, 1564 n.5 (11th Cir. 1996) (explaining that PURPA "relax[ed] restrictions on entry into the (former monopolist's) service area"). 
backup power to, or to buy excess power from, new entrants because they would likely steal the utilities' largest customers.

In the electric power industry, Congress sought to overcome these obstacles in much the same way that it later would in the Telecom Act. It placed positive duties on the electric utilities to interconnect with the new generators for the purpose of buying and selling power, ${ }^{132}$ directing the Federal Energy Regulatory Commission to issue rules and regulations, and also directing state public utility commissions to implement those rules. ${ }^{133}$

Not surprisingly, electric utilities did not respond as cooperatively as the new generators would have liked. Inevitably, failed projects led to a bevy of antitrust suits that amounted to a prequel to the antitrust litigation that has followed the 1996 Act. ${ }^{134}$ Unlike the ILECs, electric

132. The legislative history of PURPA recognized:

that two problems impeded the development of nontraditional generating facilities: (1) traditional electricity utilities were reluctant to purchase power from, and to sell power to, the nontraditional facilities, and (2) the regulation of these alternative energy sources by state and federal utility authorities imposed financial burdens upon the nontraditional facilities and thus discouraged their development.

Fed. Energy Regulatory Comm'n v. Mississippi, 456 U.S. 742, 750-51 (1982) (footnotes omitted); see also 16 U.S.C. § 824a-3(e) (directing FERC to prescribe implementing rules).

133. 16 U.S.C. $\S 824 a-3(\mathrm{e})-(\mathrm{f})$; Conn. Light and Power Co., 70 F.E.R.C. 61,012 (1995). State utility commissions were granted "latitude in determining the manner in which the regulations are to be implemented. Thus, a state commission may comply with the statutory requirements by issuing regulations, by resolving disputes on a caseby-case basis, or by taking any other action reasonably designed to give effect to FERC's rules." Fed. Energy Regulatory Comm'n v. Mississippi, 456 U.S. at 751. Should a state commission fail to implement FERC's rules, however, PURPA authorizes FERC to enforce the statute's requirements in federal court. 16 U.S.C. § 824a-3(h).

134. Representative claims included allegations that utilities:

(1) Refused to buy power on the terms required by an interconnection agreement. See TEC Cogeneration, 76 F.3d at 1567 (alleging that the utility "paid cogenerators too little for their excess power”); Schuylkill Energy Res., Inc. v. Pa. Power \& Light Co., 113 F.3d 405, 412 (3d Cir. 1997) (alleging that utility disingenuously invoked system emergency exception to power purchase contract in order to avoid purchases); Indeck Energy Servs., Inc. v. Consumers Energy Co., No. 97-CV10366-BC, 1999 U.S. Dist. LEXIS 7251, at *6 (E.D. Mich. Mar. 31, 1999) (alleging a utility's refusal "to enter into a power purchase agreement, and [to provide] meaningful access to interconnect to [the utility's] transmission systems"); Destec Energy, Inc. v. S. Cal. Gas Co., 5 F. Supp. 2d 433, 437 (S.D. Tex. 1997) (alleging that utility refused to enter power purchase contract without "transport-or-pay" provision).

(2) Cut their own rates to particular customers to dissuade such customers from building competitive power generators. See TEC Cogeneration, 76 F.3d at 1567 (alleging that the utility "offered lower rates to customers considering cogeneration"); Indeck Energy Servs, 1999 U.S. Dist. LEXIS 7251, at *5-6 (alleging that the utility offered lower rates conditioned on exclusive dealing with the utility); United States v. Rochester Gas \& Elec. Corp., 4 F. Supp. 2d 172, 173 (W.D.N.Y. 1998) (alleging that the utility entered "a contract with the University of Rochester ... whereby [the utility] promised to provide electricity ... at reduced rates in return for, inter alia, the University's promise not to compete”).

(3) Adopted other practices designed to discourage competition. See TEC Cogeneration, 
utilities focused squarely on the antitrust state action doctrine. ${ }^{135}$ And while they met with mixed success, no court held the doctrine inapplicable because PURPA was a federal statute. ${ }^{136}$

\section{SiX DEGREES OF CONNECTION BETWEEN COMPETITION- ENHANCING, INDUSTRY-SPECIFIC REGULATORY STATUTES AND THE ANTITRUST LAWS}

The courts have reached divergent results in the telecom-antitrust cases because they have effectively employed two different modes of legal analysis. This Part explains the courts' confusion about which doctrine to apply in the telecom-antitrust cases by showing that neither doctrine is adequate. Instead of the "yes or no" approach to antitrust enforcement that is appropriate where regulation serves other public policy goals, a more nuanced analysis is required when Congress itself makes competition policy. A court must first consider how antitrust enforcement would impact the implementation of the competitionenhancing regulatory program. Then, if antitrust would not interfere, a court must proceed to consider how the existence of regulatory duties should affect antitrust analysis. In answering these questions, a court will be called upon to choose one of six degrees of connection between antitrust law and a competition-enhancing, industry-specific regulation.

76 F.3d at 1567 (alleging that the utility "proposed higher rates for backup power sold to cogenerators" and interfered with interconnection by imposing "unreasonable terms in the interconnection agreement"); Indeck Energy Servs., 1999 U.S. Dist. LEXIS 7251 , at *6 (alleging the utility's refusal "to negotiate in good faith a standby power agreement"); Rosemount Cogeneration Joint Venture v. N. States Power Co., No. 490-279, 1991 WL 13729, at*1 (D. Minn. Jan. 18, 1991) (alleging that the utility prevented competitive facility from being constructed by "withdr[awing] its support from the project... and ... obtruct[ing] plaintiffs' access to municipal solid waste which was a possible fuel source for the facility").

135. See TEC Cogeneration, 76 F.3d at 1567-70 (refusing to scrutinize utility conduct under antitrust laws); Indeck Energy Servs., 1999 U.S. Dist. LEXIS 7251, at *7-11; Rochester Gas and Elec. Corp., 4 F. Supp. 2d at 175; Destec Energy, 5 F. Supp. 2d at 44458; Rosemount Cogeneration Joint Venture, 1991 U.S. Dist. LEXIS 1504, at *10-12.

136. For cases rejecting the antitrust state action defense see Rochester Gas and Electric Corp., 4 F. Supp. 2d at 175-76; Rosemount Cogeneration Joint Venture, 1991 U.S. Dist. LEXIS 1504 , at $* 10-12$.

For cases upholding the antitrust state action defense see TEC Cogeneration, 76 F.3d at 1570; Indeck Energy Servs., 1999 U.S. Dist. LEXIS 7251, at *20-21; N. Star Steel Tex., Inc. v. Entergy Gulf States, Inc., 33 F. Supp. 2d 557, 565-67 (S.D. Tex. 1998); Destec Energy, 5 F. Supp. 2d at 458. 


\section{A. Distinguishing Existing Doctrine}

Whenever courts consider a conflict between antitrust and another regulatory scheme, their task is to accommodate both laws in a way that best advances the purposes of each. Existing doctrine was developed to address potential conflicts between antitrust and regulatory programs that serve a public policy goal other than competition. For example, PURPA was enacted to lessen reliance on fossil fuel, a public policy goal not necessarily consistent with enhancing competition. In that context, both antitrust law and industry-specific regulation may coexist without compromising the goals of either. As a result, implied immunities are appropriately disfavored. The laws' purposes are best served if both apply fully.

Where governmental actors actively supervise business conduct with a noncompetition-enhancing regulatory program, courts refuse to scrutinize the conduct under the antitrust laws. Often, competitive policy can coexist with the alternative public policy goal. But regulators are considered to be more capable of balancing competing goals than the courts. In these cases, the antitrust state action doctrine assumes that the legislature incorporated into its regulatory framework whatever consideration of competitive policy it deemed appropriate and assigned that task to regulators. So long as the governmental oversight is sufficiently active, court enforced antitrust duties would interfere or conflict with the agency enforced regulatory duties. Indeed, this is the sort of conflict that the U.S. Supreme Court likely had in mind in the implied immunity cases.

In theory, courts could also balance competition and other public policy goals. In practice, however, courts limit their inquiries to competition-based arguments. ${ }^{137}$ Regulators are better situated to take account of noncompetition goals and balance them against competitive considerations. Where regulators have no duty to consider competition on an ongoing basis, however, their level of supervision may not be sufficiently active to remove the conduct from the scope of antitrust, and the courts will scrutinize the conduct under the antitrust laws as if the regulation did not exist. ${ }^{138}$ The Court's decisions in the securities regulation cases provide

137. See Nat'l Soc'y of Prof'l Eng'rs v. United States, 435 U.S. 679, 690-92 (1978). "[T] he statutory policy precludes inquiry into the question [of] whether competition is good or bad." Id. at 695 .

138. In some cases, the Court has applied the antitrust laws despite the legislature's vesting authority in a regulatory body to consider competitive factors. In these cases, the Court appears to have been concerned that Congress did not grant the regulatory body sufficient authority to actively supervise the conduct in question. For example, in United States v. Philadelphia National Bank, the Court stressed that authority to take competition into account in reviewing a merger was insufficient to supplant the antitrust 
examples. In Silver v. New York Stock Exchange, there was no active governmental supervision of the challenged conduct, and the Court held antitrust scrutiny to be appropriate. ${ }^{139}$ In Gordon v. New York Stock Exchange, Inc., the Court trusted government regulators to balance the goals of securities regulation and antitrust. ${ }^{140}$ It was not that competition did not have a role to play in the securities industry. It simply had to be applied with due regard for other goals. While "the sole aim of antitrust legislation is to protect competition," the Court explained, "the SEC must consider, in addition, the economic health of the investors, the exchanges, and the securities industry."141 Where competing public policy goals exist and governmental actors supervise private competitors, imposing the full panoply of antitrust duties would disrupt the regulatory structure and potentially interfere with the pursuit of either goal. As Justice Blackmun explained in Gordon:

Given the expertise of the SEC, the confidence the Congress has placed in the agency, and the active roles the SEC and the Congress have taken, permitting courts throughout the country to conduct their own antitrust proceedings would conflict with the regulatory scheme authorized by Congress rather than supplement that scheme. ${ }^{142}$

\section{B. Developing Accommodation Doctrine for Competition-Enhancing Regulation}

Existing doctrine is inadequate to deal with competition-enhancing regulation. On the one hand, it is not enough to ask whether there is a conflict in policies. When regulation serves competitive ends, the goals obviously do not conflict. But a regulatory program might nonetheless be compromised by the duties imposed by the general antitrust laws. On the other hand, when regulation serves competitive ends, a court cannot

\footnotetext{
laws where the reviewing agency did not have broad, continuing authority to supervise competitive factors. United States v. Phila. Nat'l Bank, 374 U.S. 321, 350-51 (1963) (stressing the limited duty to consider competition in reviewing merger and absence of continuing regulatory oversight of competitive factors); see California v. Fed. Power Comm'n, 369 U.S. 482, 486 (1962) (same).

139. See supra Part III.A.2.

140. Id.

141. Gordon v. N.Y. Stock Exch., Inc., 422 U.S. 659, 689 (1975).

142. Id. at 689-90; see United States v. Nat'l Ass'n of Sec. Dealers, Inc., 422 U.S. 694, 735 (1975) (" $[\mathrm{M}]$ aintenance of an antitrust action for activities so directly related to the SEC's responsibilities poses a substantial danger that appellees would be subjected to duplicative and inconsistent standards. This is hardly a result that Congress would have mandated.").
} 
assume that even a highly supervised regulatory program should displace antitrust enforcement. While regulators may well be better positioned than courts to balance competition and noncompetition oriented public policy goals, where the only goal is enhanced competition, courts are at least equally capable.

In developing doctrine for competition-enhancing regulation, a court must begin by recognizing that antitrust duties might interfere with regulatory duties even where there is little direct governmental oversight. Just because regulation and antitrust seek the same goal does not mean that both can be consistently applied. But there is also no a priori reason to assume that both statutes cannot be consistently applied. All regulation is not of a piece. Inevitably, regulatory programs will differ in the requirements imposed and the means of implementation. A court must be sensitive to these differences and the effect that antitrust may have on them.

Judge Wood's Goldwasser opinion illustrates the challenge by ignoring it. She concludes that it would be "illogical ... to equate a failure to comply with the 1996 Act with a failure to comply with the antitrust laws." 143 Recognizing that "there are countless laws that a firm with market power might violate that have little or nothing to do with its position in the market," she contended that a violation of a regulatory duty cannot "support an antitrust claim." 144

While that is true with respect to regulatory statutes that in fact have "little or nothing to do" with competition, when the purpose of industryspecific regulation is to enhance competition, a violation of that statute has everything to do with the firm's competitive position. There may be reasons not to layer antitrust duties atop regulatory duties, but logic has nothing to do with them. A court must look carefully at the requirements imposed by the statute and the means used to implement it.

This inquiry should be approached in two stages. First, a court should ask how imposing traditional antitrust duties on regulated firms would affect the regulatory program. If antitrust enforcement would undermine the ability of the regulators to spur the competition envisioned by the legislature in enacting the industry-specific regulation, then courts should not scrutinize conduct under the antitrust laws. Second, if antitrust enforcement would not disrupt the regulatory program, then a court should consider how the regulatory statute might affect antitrust analysis.

143. Goldwasser v. Ameritech Corp., 222 F.3d 390, 400 (7th Cir. 2000).

144. Id. (citing the following situations as examples: "an agricultural firm might fail to comply with safety or cleanliness standards applicable to food processing; a computer processor firm might violate employment discrimination laws; a pharmaceutical firm might run afoul of the Food and Drug Administration's rules for approval of new drugs"). 


\section{Whether Antitrust Enforcement Would Interfere with a Procompetitive Regulatory Program}

This Subsection clarifies the first step in the analysis by preempting possible confusion about what is not involved. It then articulates a test for determining whether antitrust enforcement can coexist with a competition-enhancing regulatory program.

\section{a. Focusing on How Imposing Antitrust Duties Would Affect Regulatory Duties}

In approaching the question of how antitrust enforcement might undermine the procompetitive goals of an industry-specific statute, it is important to focus on what is not at issue. First, the necessary inquiry is much different from that undertaken with respect to the antitrust state action doctrine. That doctrine focuses on legislative displacement of competition and active supervision to ensure that the anticompetitive conduct is in fact serving the noncompetitive regulatory goal. Where regulation seeks to enhance competition, asking whether the legislature sought to displace competition and whether regulators supervise anticompetitive conduct are nonsensical questions. Instead, a court should focus on whether the legislation, along with accompanying regulations, channel competitive behavior such that antitrust enforcement might prove disruptive.

Supervision will still be relevant, but in a different way. In prior cases, the issue was whether governmental actors were driving the policy decisions. If they were, then the conduct was deemed to be outside the scope of antitrust. ${ }^{145}$ Where regulation seeks to enhance competition, the level of supervision is not as important as the structure of the regulation. Antitrust enforcement might serve positively to augment even very actively supervised conduct, because both regulators and courts would be advancing the same goal. Alternatively, antitrust might disrupt a program with relatively little government supervision. For example, a regulatory statute might require certain competitors to set jointly a percentage mark-up over wholesale prices in order to spur competition from resellers of the product in question. Allowing antitrust attack on the joint conduct would undermine the regulation irrespective of the level of government supervision over the prices set.

145. See supra Part III.A.2. 
Second, the focus must be on substantive antitrust duties, not remedies. Injunctive antitrust remedies could disrupt virtually any regulatory program because, in theory, judges could order parties to alter anticompetitive practices in ways that differ from the methods employed by the regulation. Because judges have discretion in imposing injunctive relief, however, they are also capable of tailoring that relief so as to minimize disruption. ${ }^{146}$ The appropriate question is not whether antitrust remedies could disrupt a regulatory program, but rather whether layering antitrust duties on top of the regulatory duties would disrupt the program. Would competitors in the industry be hindered in their ability to fulfill their regulatory obligations if they were also required to meet the antitrust standards of conduct ordinarily required of law abiding companies?

\section{b. Rejecting Antitrust in Favor of Competition-Enhancing Regulation}

Where antitrust would pervasively interfere with a regulatory program, competitors in the industry should be free of antitrust duties. This complete exemption could be appropriate in instances where the legislature sought to structure the industry in a more orderly way than free competition would allow. Competition can be chaotic. Long range planning in a competitive market is uncertain. Where the legislature indicates that certainty is essential to enable new competitors to enter the market, any antitrust enforcement may interfere with the regulatory program. ${ }^{147}$ Alternatively, and more likely, only certain regulatory duties will be compromised by antitrust enforcement. In that case, only a competitor's conduct that falls within those particular regulatory duties would be exempted from the antitrust laws.

The first degree of antitrust-regulatory connection thus calls for no connection at all. Regulation trumps antitrust entirely. The next Subsection addresses the remaining five degrees in which antitrust continues to apply, and the relevant question is what effect, if any, the regulatory statute has on antitrust analysis.

146. See Brief of Amici Curiae United States and the Federal Communications Commission as Amici Curiae at 15, Covad Communications Co. v. BellSouth Corp., 299 F.3d 1272 (11th Cir. 2002) (No. 01-16064-C); Brief for the United States and Federal Communications Commission as Amici Curiae in Support of Appellants at 12-13, Intermedia Communications, Inc. v. BellSouth Telecomms., Inc. (11th Cir. filed Jan. 12, 2001) (No. 01-10224-JJ). For an excellent discussion of the ways that courts should take regulation into account in imposing antitrust remedies see Weiser, supra note 96.

147. Town of Concord v. Boston Edison Co., 915 F.2d 17, 22 (1st Cir. 1990) ("An antitrust rule that seeks to promote competition but nonetheless interferes with regulatory controls could undercut the very objectives the antitrust laws are designed to serve."); IA AREEDA \& HOVENKAMP, supra note 2, ๆ 242b (explaining that "where the regulatory regime controls such things as pricing, entry by new firms, joint market behavior, mergers, or possible exclusionary practices by dominant firms, then an antitrust immunity may be essential if regulatory goals are not to be frustrated"). 


\section{How Regulation Affects Antitrust}

If antitrust and the regulatory program can exist side by side without interfering with regulatory duties, courts should go on to consider how the regulatory program might affect antitrust analysis. Under existing doctrine, if antitrust continues to apply, a court must generally apply it as if the regulation did not exist. Since courts are poorly equipped to balance public policy goals, the specifics of the regulation play no role in their antitrust analysis. But the picture changes when the goal of the regulation is to enhance consumer welfare.

Competition-enhancing regulation will assuredly involve explicit legislative decisions about the type of conduct necessary to foster a competitive environment in that industry. While there are situations where those duties should appropriately be ignored in applying antitrust law, in others the legislature's regulatory decisions will be of critical importance to courts in defining antitrust obligations.

Antitrust analysis is an inexact science, and that uncertainty necessarily affects what courts do. There are often no objective facts to which courts may turn to determine whether a particular practice enhances competition, harms competition, or is competitively neutral. ${ }^{148}$ Because of its uncertainty, leading judges and commentators have sought to put off or eliminate this inquiry altogether. ${ }^{149}$ The courts have rejected that approach and have instead relied on burdens and presumptions as a proxy for proof of actual anticompetitive effects. A

148. Professors Areeda and Hovenkamp explain that "the legality of a challenged practice under the antitrust laws will often depend on a court's judgment about the degree of social harm that might result from the challenged practice, the social benefits that might be obtained through that practice, and the availability of significantly less restrictive alternatives." IA AREEDA \& HOVENKAMP, supra note 2, \ 240c3.

149. See Rothery Storage \& Van Co. v. Atlas Van Lines, Inc., 792 F.2d 210 (D.C. Cir. 1986).

[T]hough it is sometimes said that, in the case of restraints like these, it is necessary to weigh procompetitive effects against anticompetitive effects, we do not think that a useable formula if it implies an ability to quantify the two effects and compare the values found... . Weighing effects in any direct sense will usually be beyond judicial capabilities but predictions about effects may be reflected in rules about allowable size. ... Antitrust adjudication has always proceeded through inferences about market power drawn from market shares.

Id. at 229 n.11. See generally Frank H. Easterbrook, The Limits of Antitrust, 63 TEX. L. REV. 1, 17-39 (1984) (proposing filters to permit antitrust cases to be dismissed without reaching the competitive harm question); Frank H. Easterbrook, Predatory Strategies and Counterstrategies, 48 U. CHI. L. REV. 263 (1981) (proposing that low pricing campaigns be treated as legal per se because of the difficulty of resolving the competitive harm question). 
plaintiff bears the burden of proving that the defendant has a high market share and that barriers to market entry exist. If a plaintiff overcomes that burden, it encounters a second burden to prove that the defendant's specific conduct is predatory or exclusionary. This sort of conduct is defined as actions or omissions "other than competition on the merits ... that reasonably [appear] capable of making a significant contribution to creating or maintaining monopoly power." 150 Finally, if the defendant responds with procompetitive justifications for the challenged conduct, the plaintiff must show that the procompetitive benefits could be achieved through less restrictive means or that, on balance, the defendant's conduct is anticompetitive.

In applying these burdens and presumptions, courts must wrestle with the concern that procompetitive behavior will be discouraged if it is too easy to maintain a plausible antitrust case. ${ }^{151}$ If the measure of cost in predatory pricing cases were too high, for example, firms would be discouraged from making procompetitive price cuts in order to guard against antitrust litigation, if not liability. This concern leaves courts

150. Town of Concord, 915 F.2d at 21 (quoting 3 Philip AREedA \& DonAld TURner, ANTITRUST LAW ๆ 626 (1978)); see Aspen Skiing Co. v. Aspen Highlands Skiing Corp., 472 U.S. 585, 605 (1985) (defining predatory or exclusionary conduct as conduct that tends to "exclude rivals on some basis other than efficiency" (quoting Robert H. Bork, The Antitrust Paradox: A Policy at War with Itself 138 (1978))); III Phillip E. Areeda \& Herbert Hovenkamp, Antitrust Law: An ANALYSIS OF ANTITRUST PRINCIPLES AND ThEIR APPLICATION \ 650a (1996) ("In order to satisfy any conduct component of the monopolizing offense, the conduct in question must be capable of making a significant contribution to the creation, maintenance, or expansion of monopoly power.").

151. See Barry Wright Corp. v. ITT Grinnell Corp., 724 F.2d 227, 234 (1st Cir. 1983) (explaining that "we must be concerned lest a rule or precedent that authorizes a search for a particular type of undesirable pricing behavior end up by discouraging legitimate price competition"); see also Brooke Group Ltd. v. Brown \& Williamson Tobacco Corp., 509 U.S. 209, 223 (1993) (referring to the "intolerable risks of chilling legitimate price cutting”); Copperweld Corp. v. Independence Tube Corp., 467 U.S. 752, 775 (1984) (explaining that "[s]ubjecting a single firm's every action to judicial scrutiny for reasonableness would threaten to discourage the competitive enthusiasm that the antitrust laws seek to promote"). In Goldwasser, the court explained that:

It is not enough that a single firm appears to "restrain trade" unreasonably, for even a vigorous competitor may leave that impression. For instance, an efficient firm may capture unsatisfied customers from an inefficient rival, whose own ability to compete may suffer as a result. This is the rule of the marketplace and is precisely the sort of competition that promotes the consumer interests that the Sherman Act aims to foster. In part because it is sometimes difficult to distinguish robust competition from conduct with longrun anticompetitive effects, Congress authorized Sherman Act scrutiny of single firms only when they pose a danger of monopolization. Judging unilateral conduct in this manner reduces the risk that the antitrust laws will dampen the competitive zeal of a single aggressive competitor.

Goldwasser v. Ameritech Corp., 222 F.3d 390, 397 (7th Cir. 2000) (quoting Copperweld Corp. v. Independence Tube Corp., 467 U.S. 752, 767-68 (1984)). 
appropriately cautious about finding particularly unilateral conduct to be predatory.

But this caution about section 2 cases is seriously undermined where the legislature concludes that cooperation is a competitive necessity. Walling off the area of prosecution dramatically reduces the concern with false positive errors. ${ }^{152}$ Not all firms would need to worry, only those in the regulated industry, and the legislature obviously wanted those firms to worry about conduct of this sort.

The task for a court at this stage is to determine how much the regulatory proscription should influence antitrust analysis by eliminating one or more of the three burdens - market power, likely anticompetitive effect, and rebuttal of procompetitive justifications - that are ordinarily placed on an antitrust plaintiff. ${ }^{153}$ This Subsection describes five additional degrees of connection between a regulatory statute and the antitrust laws. The regulatory statute might:

(1) have no impact whatsoever on the application of the antitrust laws to the industry,

(2) create a presumption that a violation of the regulatory statute has anticompetitive effects if the plaintiff proves that the defendant has market power in a relevant market and the defendant has inadequate procompetitive justifications for the act,

(3) create a presumption that a violation of the regulatory statute has anticompetitive effects even absent proof of market power if the

152. $C f$. Steven Semeraro, Note, Distinguishing International from Domestic Predation: A New Approach to Predatory Dumping, 23 STAN. J. INT'L L. 621, 640, 644-45 (1987) (demonstrating that aggressive enforcement of predatory pricing cases in the international arena will not deter aggressive price competition generally because regulatory antidumping mechanisms and the clear distinction between international and domestic conduct effectively limits the firms exposed to antitrust liability).

153. That courts must temper antitrust analysis to account for noncompetition-enhancing regulation is well accepted. IA AREEDA \& HovENKAMP, supra note 2, ๆ 240c3 (explaining that "the existence of a special regulatory statute may insulate the court from its usual assumptions about industrial behavior and the social good and even render a per se rule inapplicable"). The approach suggested here applies the same reasoning - that the flexible antitrust laws must adapt to the specifics of an industry - to expand antitrust in light of competition enhancing regulation. While less often discussed, this possibility is not entirely new to the literature. $I d$. $9240 \mathrm{~d}$.

$[\mathrm{T}]$ he presence of regulation in some instances limits the antitrust role, and in some instances simply changes it or even enlarges it. The impact depends on the nature of the regulatory regime, the nature of the antitrust claim, and the Id. degree of supervision given by the agency to the challenged conduct. 
defendant has inadequate procompetitive justifications for the act,

(4) create a presumption that a violation of the regulatory statute is per se illegal if the plaintiff proves that the defendant has market power in a relevant market, or

(5) create a presumption that a violation of the regulatory statute should be treated as a per se antitrust violation regardless of proof of market power or potential procompetitive justifications.

A court's choice among these will turn on the regulatory methods used and the findings underlying them. To pinpoint just how influential the regulation should be, a court must consider the competitive conclusions evinced by the legislation. A marketplace duty intended to enhance competition necessarily suggests a finding that the breach of that duty is potentially anticompetitive. Whether the legislature would find that the conduct is anticompetitive absent market power or in spite of procompetitive justifications requires a harder look.

\section{a. The Neutrality Position}

Regulation should not influence antitrust analysis where the competition-enhancing regulatory duty does not directly influence marketplace behavior. For example, regulation that creates an obligation to file reports on market conditions with a government agency would bear little relation to marketplace competition. Duties of that sort have no bearing whatsoever on the application of the antitrust laws, and those laws should thus apply as if the regulatory statute did not exist.

Where a legislature seeks to enhance competition by influencing marketplace behavior, however, its requirements will likely have some relevance to antitrust analysis, and this degree of separation will be inappropriate.

\section{b. Treating Regulatory Violations as Predatory Acts Where Market Power Is Shown and the Defendant Has Inadequate Procompetitive Justifications}

A legislature's decision to require certain conduct in order to facilitate greater competition would, by definition, equate to a finding that a defendant's failure to engage in the required conduct may have some anticompetitive effect. Given that competitive effects are difficult to measure, courts should defer to this legislative finding. That conduct may lessen competition, however, does not mean that it actually does. Generally, a firm without market power is incapable of significantly reducing consumer welfare because consumers have other options. And even firms with market power may show that anticompetitive conduct 
simultaneously promotes competition to such an extent that, on balance, the conduct would not violate the antitrust laws. Where the legislature's findings are unclear, the plaintiff should be required to rebut a defendant's procompetitive justifications.

This degree of separation differs from the neutrality position only in that a plaintiff that establishes the defendant's market power in the relevant market need not also demonstrate that the allegedly predatory conduct is likely to have a substantial anticompetitive effect. ${ }^{154}$ The plaintiff would also retain the burden of responding to any procompetitive justification proffered by the defendant. Some regulatory statutes may support relieving the plaintiff of even more burdens. Those possibilities are considered below.

\section{c. Identifying Predatory Acts Unless a Procompetitive Purpose Is Proven}

In some cases, a regulatory statute might place regulatory duties on firms that do not have market power. It might adopt this approach where the cooperative conduct was deemed essential to effective competition, and waiting for the marketplace to punish uncooperative competitors without market power would be needlessly wasteful. This sort of legislative finding is analogous to the so-called quick look approach. ${ }^{155}$ In general, courts must exercise great caution in dispensing with market power analysis. Where the legislature has determined that certain conduct is essential to competition irrespective of market power, however, courts should typically reach the same conclusion.

Whenever antitrust liability may rest on firms without market power, there is a greater danger that conduct without anticompetitive effect will be subject to punishment. It will therefore be appropriate in most cases to give the defendant the opportunity to demonstrate a procompetitive justification for its conduct that could not be achieved without violating the regulatory requirement.

154. In a private action, a plaintiff would also need to demonstrate that it suffered antitrust injury and otherwise had standing to pursue the action. See Associated Gen. Contractors, Inc. v. Cal. State Council of Carpenters, 459 U.S. 519, 529-46 (1983); Brunswick Corp. v. Pueblo Bowl-O-Mat, Inc., 429 U.S. 477, 489 (1977).

155. See, e.g., Fed. Trade Comm'n v. Ind. Fed'n of Dentists, 476 U.S. 447, 457-59 (1986). 


\section{d. Acts that Are Predatory Per Se if Market Power Is Proven}

In other cases, the legislature may indicate, expressly or impliedly, that it intends to place regulatory duties only on firms with market power. Even where the legislature does not explicitly mention market power, the regulatory duties it imposes may rest on the assumption that the burdened firms possess it. As a regulatory program unfolds and competitive conditions in the marketplace change, a firm's dominance may wane. Thus, the prudent course would often be to require the plaintiff to prove that the defendant has market power before finding that the antitrust laws are violated.

At the same time, however, the statute may indicate that the legislature has considered, and rejected, the possibility of procompetitive justifications for the failure to undertake particular conduct. This finding may be inferred from specific, compulsory regulatory requirements.

\section{e. Per Se Condemnation}

Finally, a legislature may condemn a competitive practice so strongly and without regard to market power that courts should treat that practice as a per se violation of the antitrust laws. A court should adopt this level of connection very cautiously. The legislature must clearly communicate that violating the specific duty would have no redeeming virtues. As with the prior degree of separation, the duty must be compulsory and void of exceptions. Beyond that, the penalty should be harsh. For example, if a regulatory statute subjected violators to criminal penalties or stiff civil fines, per se analysis under the antitrust laws might be appropriate.

Courts are generally reluctant to identify conduct as per se illegal under the antitrust laws without substantial experience with the practice. ${ }^{156}$ But where the legislature decides that certain conduct is anticompetitive in a particular industry, and adopts strong remedies against it, the courts need not make the difficult decision. The legislature has reached a conclusion that the courts may safely implement.

As a practical matter, no practice is per se illegal in all circumstances. Even price fixing requires some inquiry into market conditions before it is condemned. ${ }^{157}$ Courts implying per se antitrust rules from regulatory statutes should thus remain alert to the potential need for some contextual analysis. But like the per se rules against price fixing and horizontal market division, transgressing a regulatory statute of this type would create a very strong presumption in favor of an antitrust violation.

156. See White Motor Co. v. United States, 372 U.S. 253, 263 (1963).

157. See supra note 112 and accompanying text. 
Indeed, the presumption could be even stronger than that for per se rules generally because the legislature has already decided to prohibit a practice within a particular industry.

\section{SeParation Between the Telecom ACt AND the ANTITRUST LAWS}

This Part applies the doctrine proposed in Part IV and concludes that the duties imposed by the Telecom Act can effectively coexist with antitrust duties. To determine how the 1996 Act should affect antitrust analysis, courts need to differentiate between the two sets of duties imposed by the Act. Certain duties apply to all telecom providers while others apply only to ILECs. In either case, a court should presume that (1) a violation of the Act substantially contributes to the maintenance of an ILEC's market power, but (2) a plaintiff should retain the burden of rebutting procompetitive justifications proven by the defendant. For duties placed on all competitors, the court should not require proof of market power. For ILEC only duties, however, the court should demand proof of market power before shifting the burden to the defendant to come forward with a procompetitive justification. The final Section addresses the types of antitrust claims that would be entitled to this presumption.

\section{A. Imposing Antitrust Duties Would Not Undermine the Effectiveness of the Telecom Act}

The duties generally imposed by the antitrust laws would not conflict with the means used by the Telecom Act to achieve its procompetitive goals. The 1996 Act is designed to foster competition in local telephone service by requiring ILECs to provide potential competitors with the means to enter the market. While the antitrust laws do not typically compel the sort of cooperation required by the Act, it is also not the type of cooperation that would ordinarily raise competitive concerns. For example, the Act requires ILECs to interconnect with competitors. Network markets are usually interconnected because consumers demand it. Bank ATM machines, methods of computer file transfer, and long distance telephone service are examples of situations in which consumers demand interconnection and marketplace forces lead to it. Thus, there is little fear that imposing antitrust duties would lead a firm to refuse to interconnect as required by the Act.

Similarly, the Act requires ILECs to sell local service at wholesale 
prices and essentially rent network elements - component parts of the network needed to provide local service - to their competitors. Many manufacturers do essentially the same thing without raising antitrust concern. For example, film manufacturers wholesale film for private label sale in competition with their own branded product, and automobile manufacturers provide parts, and sometimes even entire cars, to competitive manufacturers.

One might argue that the extensive sharing requirements that the 1996 Act imposes on the ILECs extend beyond the sort of sharing arrangements that we see in unregulated markets. At some point, enforced duties to share must have anticompetitive consequences that would conflict with the duties imposed by the antitrust laws. As Justice Breyer explained in his concurrence in AT\&T Corp. v. Iowa Utilities Board:

It is in the unshared, not in the shared, portions of the enterprise that meaningful competition would likely emerge. Rules that force firms to share every resource or element of a business would create not competition, but pervasive regulation, for the regulators, not the marketplace, would set the relevant terms. ${ }^{158}$

The anticompetitive effect of sharing could be particularly pernicious with respect to innovation. A new firm may not strive to innovate if it can simply share an incumbent's technology, and an incumbent's incentives to innovate are reduced when it is forced to share the fruits of its labor. ${ }^{159}$

These potential concerns do not reveal a conflict between the 1996 Act and antitrust duties. Although the statutory language is perhaps open to the interpretation that anticompetitive sharing is required, it is open to the alternative interpretation as well. Given Congress's purpose to encourage competition, the latter reading of the statute is obviously more appropriate. Toward that end, the Court has required the FCC to distinguish those elements that must be shared from those that need not be shared. ${ }^{160}$

Even if the Act were interpreted to require ILECs to share any requested element, the duties it imposes would not necessarily conflict with antitrust duties. After all, the Act does not compel royalty free sharing. It merely prohibits the ILEC from refusing to share, for a cost based royalty plus reasonable profit, when a CLEC requests access to an

158. AT\&T Corp. v. Iowa Utils. Bd., 525 U.S. 366, 429 (1999) (Breyer, J., concurring in part and dissenting in part).

159. Id. (Breyer, J., concurring in part and dissenting in part) (explaining that a firm may not "undertake the investment necessary to produce complex technological innovations knowing that any competitive advantage deriving from those innovations will be dissipated by the sharing requirement").

160. Id. at 386-95; see id. at 429-30 (Breyer, J., concurring in part and dissenting in part); Federal Communications Commission Adopts New Rules for Network Unbundling Obligations of Incumbent Local Phone Carriers, http://hraunfoss.fcc.gov/edocs_public/ attachmatch/DOC-231344A1.pdf (Feb. 20, 2003). 
element. Competition would persist under such a scheme so long as two conditions are met. First, competition must be possible in some elements. If a monopolist could always produce all elements more efficiently than a competitor, then competition would not emerge. But the 1996 Act rests on the assumption that all aspects of local telephone service are not natural monopolies. Second, the royalty must not be set too low. So long as the royalty properly reflects the ILEC's cost, plus a reasonable profit, ${ }^{161}$ competition in that element will emerge whenever a CLEC can produce the element more efficiently. A CLEC would not request to share an element - and pay a cost-plus-profit-based royalty for it - unless it could not duplicate the element on its own at a lower cost than the ILEC. All things being equal, this regime might reduce an ILEC's incentive to innovate as compared with a monopoly situation in which innovations need not be shared. But all things would not be equal. Congress likely concluded that the competition from CLECs made possible by the Act would spur more innovation throughout the industry.

While the Act on its face does not appear to raise any conflicts with antitrust duties, a court should go beyond an examination of the regulatory methods in the Act and examine other indications of legislative and regulatory intent. Here again, there is much evidence to suggest that imposing antitrust duties would not disrupt the regulatory program. The antitrust savings clauses, the 1996 Act's legislative history, ${ }^{162}$ early FCC commentary, ${ }^{163}$ and contemporary statements by the President, ${ }^{164}$ members of Congress, ${ }^{165}$ and Joel Klein, then-Assistant

161. Setting an appropriate price through regulation has stirred debate among regulators, competitors, and the courts. $C f$. Iowa Utils. Bd., v. Fed. Communications Comm'n, 219 F.3d 744, 750 (8th Cir. 2000), rev'd sub. nom., Verizon Communications, Inc. v. FCC, 122 S. Ct. 1646, 1665-81 (2002).

162. See H.R. CONF. REP. No. 104-458, at 201 (1996) (explaining that the savings clause "prevents affected parties from asserting that the [Act] impliedly preempts other laws" and that the FCC "should be carrying out the policies of the Communications Act, and the DOJ should be carrying out the policies of the antitrust laws"); S. REP. NO. 10423, at 17 (1995) ("[T]he provisions of this bill shall not be construed to grant immunity from any future antitrust action against any entity referred to in the bill.").

163. See Implementation of the Local Competition Provisions in the Telecommunications Act of 1996, 61 Fed. Reg. 45,476, 45,494 (Aug. 29, 1996) (to be codified at 47 C.F.R. pts. 1, 20, 51, 90) (explaining that "nothing in [the FCC's] regulations is intended to limit the ability of persons to seek relief under the antitrust laws").

164. Covad Communications Co. v. BellSouth Corp., 299 F.3d 1272, 1282 (11th Cir. 2002) ("The Act's emphasis on competition is also reflected in its antitrust savings clause. This clause ensures that even for activities allowed under or required by the legislation, or activities resulting from FCC rulemaking or orders, the antitrust laws 
Attorney General for the Antitrust Division of the DOJ, ${ }^{166}$ all support the view that Congress saw antitrust as a helpful supplement to the duties imposed by the 1996 Act.

Goldwasser expressed concern that antitrust duties might disrupt the Act's mandatory negotiation and regulatory dispute resolution provisions. ${ }^{167}$ To the extent that this is a concern about remedy, as explained above, we must remember that federal judges are capable of tailoring remedies to avoid conflict. A proponent of this view might argue, however, that the problem arises from the mere filing of a suit requiring a court to address the merits of a dispute not yet subjected to the appropriate regulatory channels. But just as judges can tailor antitrust remedies to avoid regulatory conflict, the primary jurisdiction doctrine enables a court to tailor the timing of litigation by staying proceedings in an antitrust case pending the resolution of regulatory proceedings. ${ }^{168}$

Goldwasser also alludes to the possibility that antitrust law might conflict with the 1996 Act because the Act may not have been intended to pursue procompetitive goals as single mindedly as antitrust law. While admitting that the duties imposed by the 1996 Act "do not conflict with the antitrust laws," Judge Wood described them as "more specific and far-reaching obligations that Congress believed would accelerate the development of competitive markets, consistently with universal service (which, we note, competitive markets would not necessarily assure)."169 While it is certainly true that Congress was concerned about maintaining universal service and that competition alone would not likely achieve that goal, the 1996 Act cannot properly be said to have the maintenance of universal service as a goal. Instead, it sought to dismantle the regulatory devices that had been used in part to achieve universal service at the expense of competition in order to enable full competition to flourish in telephony markets. To be sure, Congress provided a means to pursue universal service, but it did so in ways that would be consistent

continue to apply fully." (quoting President Clinton's statement at the signing of the bill)).

165. See id. at 1281 (quoting statements from Representative Conyers and Senators Thurmond and Leahy, emphasizing that "ILECs like BellSouth [should] remain subject to antitrust enforcement").

166. See Klein, supra note 33, at 7, at http://www.usdoj.gov/atr/public/speeches/ 1268.htm (then-Assistant Attorney General for the Antitrust Division of the DOJ explained that antitrust law may serve as a useful backup to the $1996 \mathrm{Act}$ ).

167. Goldwasser v. Ameritech Corp., 222 F.3d 390, 401 (7th Cir. 2000) (explaining that "[t]he elaborate system of negotiated agreements and enforcement established by the 1996 Act" is not "compatible with the procedures that would be used to accomplish the same result under the antitrust laws").

168. See Ricci v. Chi. Mercantile Exch., 409 U.S. 289, 301-02 (1973).

169. Goldwasser, 222 F.3d at 401 (emphasis added). 
with full competition. ${ }^{170}$ Congress's desire to maintain universal service therefore does not create any inconsistency between antitrust duties and the 1996 Act.

\section{B. The Telecom Act's Effect on the Antitrust Laws}

Having rejected complete separation between the Telecom Act and antitrust law, a court would move to the second step of the analysis to determine how, if at all, the regulatory statute should affect the application of antitrust law. This Section concludes that violations of the Act must be separated into two different categories. First, regulatory duties imposed on all local carriers should be presumed to have significant anticompetitive effect regardless of the carrier's market power. Second, duties imposed only on ILECs should be presumed to have anticompetitive effects only if market power is shown. In either case, the plaintiff should bear the burden of rebutting any procompetitive justifications offered by the defendant.

\section{Rejecting the Extreme Forms of Antitrust-Telecom Connection}

The two extreme forms of antitrust-telecom connection, complete neutrality and per se illegality, can be readily rejected. Congress's decision to require ILECs to cooperate in certain ways communicates a legislative judgment that the required cooperation is procompetitive. That judgment is relevant to antitrust analysis, and thus, the neutrality position should be rejected.

Courts should also reject the per se degree of separation. Congress did not mandate specific practices. Rather, it imposed duties in terms of goals and required competitors to negotiate and agree on the conduct necessary to achieve those goals. Further, Congress charged competitors with a duty to implement the Act in the first instance through private negotiations. ${ }^{171}$ This structure indicates that Congress

170. In re Access Charge Reform, First Report and Order, 12 FCC Rcd. 15,982 (1997). Recognizing the vulnerability of implicit subsidies to competition, Congress directed the Commission and the states to take the necessary steps to create permanent universal service mechanisms that would be secure in a competitive environment. To achieve this end, Congress directed the Commission to strive to replace the system of implicit subsidies with "explicit and sufficient support mechanisms."

Id. (footnotes omitted).

171. See Law Offices of Curtis V. Trinko, L.L.P. v. Bell Atl. Corp., 305 F.3d 89, 104 (2d Cir. 2002) ("The elaborate process of negotiation and arbitration set forth in 
envisioned a wide variety of competitive possibilities.

In addition, Congress chose not to impose harsh sanctions for violations of the Act. Such a flexible and nonpunitive regulatory structure indicates that Congress did not make the sort of black and white findings with respect to particular competitive practices that would support holding a violation of a regulatory duty per se illegal.

\section{Choosing Among the Final Three Degrees of Connection Requires More Careful Analysis}

At a minimum, Congress's decision to require ILECs to interconnect and cooperate in certain ways should relieve an antitrust plaintiff of the burden of showing that an ILEC's failure to fulfill these duties is likely to contribute substantially to the maintenance of the ILEC's market power. The 1996 Act constitutes a legislative finding that cooperation in certain areas is necessary to enable competition to serve its usual consumer-welfare-enhancing function. Courts should not second-guess that finding.

\section{a. Plaintiffs Must Prove Market Power for ILEC-Specific Duties, But Not for All LEC Duties}

The more difficult question is whether the 1996 Act should also relieve the plaintiff of the burden of proving that an ILEC has market power and that the anticompetitive effect of the ILEC's noncompliance outweighs any procompetitive justification that the ILEC may offer. The language of the statute does not limit the duties imposed to those ILECs with market power. On the contrary, the Act explicitly imposes certain duties on all local telephone service providers, even though CLECs would almost certainly have no market power. Congress's decision to impose these duties without regard to market power demonstrates that it concluded that anticompetitive effects would flow from any carrier's violation of these duties. Again, courts should not second-guess that conclusion.

Conversely, Congress placed certain duties only on ILECs, and it surely recognized that ILECs have market power. To the extent that the Act introduces competition into the local telephone service market, however, such competition should erode the ILECs' market power over time. Arguably, if Congress wanted ILEC-specific duties to apply only to ILECs that retain their market power, it would have included

section 252 indicates that Congress sought to allow ILECs and their competitors to govern their interconnection relationships directly through specific interconnection agreements rather than the broadly outlined duties described in subsections (b) and (c) of section 251."). 
provisions in the statute altering the duties at that time. By failing to address that contingency, Congress may have signaled a conclusion that even the ILEC-specific duties should apply regardless of market power.

For the existing set of telecom-antitrust cases, the issue of whether to require proof of market power makes little practical difference. The ILECs have it, and plaintiffs will be able to prove it. As long as some element of local telephone service is best provided by a single company, the ILECs are likely to maintain their market power. Indeed, Congress may have assumed that local loops connecting individual customers to the telephone system would be impossible to duplicate, leaving ILECs with long lasting market power despite the emergence of competition. But that could change. PCS or cable telephone service could emerge as effective competitors to local loop service. Should that happen, a court would need to carefully consider the impact of treating ILEC-specific duties as anticompetitive. For example, would requiring interconnection at any technically feasible point within the ILEC's network serve the same competitive ends if the ILEC no longer had market power? Maybe not. Congress chose not to impose that duty on local carriers unlikely to have market power. Conversely, effective competition might nonetheless require one system to serve as a hub to which others can interconnect at any feasible point. Answering that question will require a careful analysis of the evolved technological options that will then exist. Until it can be conclusively demonstrated that ILEC-specific duties would enhance competition even if the ILEC has no market power, antitrust plaintiffs should be required to prove that an ILEC has market power.

\section{b. Plaintiffs Must Rebut Procompetitive Justifications}

With respect to procompetitive justifications, the Act's structure indicates that an antitrust plaintiff should continue to bear the burden of proof. To be sure, the statute imposes categorical duties without explicitly recognizing the possibility that competition might be better served in some other way. Congress's decision to rely on private negotiation and mediation, rather than strict regulatory dictates, however, indicates that it recognized the need for flexibility in finding the best competitive mix. That recognition within the Act would compel a court to require a plaintiff to demonstrate either that (1) the defendant could achieve the procompetitive justifications through means less restrictive than a violation of the Act, or (2) the anticompetitive effects outweigh the procompetitive effects. 


\section{Evaluating Specific Antitrust Claims}

A likely critique of this approach to antitrust-telecom accommodation is that it would open the door to expensive and protracted litigation over questionable, if not frivolous, antitrust claims. Given the open-textured language of the antitrust laws and the contextual nature of their application, a creative plaintiffs' lawyer could frame an antitrust claim out of trivial violations of the Telecom Act, and the ensuing litigation would stifle competitive initiatives among telephone service providers.

This is a legitimate concern. As with all antitrust doctrine, the approach put forward here must be applied with careful attention to the ultimate goal of promoting consumer welfare. Some claims should pose little debate. Trivial violations of the Act should not be entitled to a presumption of anticompetitive effect. Conversely, if an ILEC violates serious duties such as the number portability or equal access requirements, presuming anticompetitive effect should raise little concern. This sort of violation bears the typical hallmarks of predatory conduct. Permitting antitrust claims to be based on violations of that type would pose little danger of stifling truly consumer-welfareenhancing competition.

Of more concern are claims that ILECs are charging prices that are too low to allow CLECs to compete. A creative attorney could no doubt frame a price squeeze, primary-line price discrimination, or predatory pricing claim as a violation of the 1996 Act. But a presumption of anticompetitive effect would be inappropriate in these circumstances. Claims alleging low pricing are treated with a cautious eye because low prices benefit consumers, and recognizing antitrust claims based on low pricing could chill what is nearly always a procompetitive practice. ${ }^{172}$ The Telecom Act cannot reasonably be read to suggest that these concerns differ in the local telephone service market. Consumers would not benefit if ILECs charged higher prices for their services.

Most difficult are antitrust claims relating to the duties requiring ILECs to (1) provide unbundled network elements, (2) sell local service at wholesale for resale by a competitor, and (3) provide space at their facilities for a competitor's equipment. ${ }^{173}$ Aggressive competition, like low pricing, nearly always benefits consumers. Permitting antitrust claims resting on a failure to fulfill these cooperative duties - or worse

172. See Brooke Group Ltd. v. Brown \& Williamson Tobacco Corp., 509 U.S. 209, 220-22 (1993) (discussing care needed in assessing predatory pricing and primary-line price discrimination cases); Town of Concord v. Boston Edison Co., 915 F.2d 17, 22-29 (1st Cir. 1990) (discussing care needed in assessing price squeeze claim, particularly in a regulated industry).

173. 47 U.S.C. $§ 251(c)(3),(4),(6)$. 
yet, presuming that a violation of these duties has anticompetitive effect-would arguably stifle the business freedom that drives aggressive competition, just as predatory pricing claims chill price cutting. ${ }^{174}$

But price cutting and refusing to cooperate pose entirely different consumer welfare scenarios. Price cutting and consumer welfare virtually always go hand in hand. Whether consumers are best served by cooperation or the refusal to cooperate, however, depends on the context of the decision. In many competitive markets, producers voluntarily cooperate in all of the ways that the Telecom Act requires of ILECs, and consumers benefit. Firms effectively (1) rent elements of their business (for example, banks enable competitors to use their ATMs), (2) sell at wholesale to their retail competitors (for example, home appliance manufacturers make their products available for private labeling), and (3) make available the facilities necessary to enable their customers to deal with competitors (for example, brokerage firms include information about competitive mutual funds in their catalogs). Firms make these accommodations to their competitors because the marketplace demands it. That is, they can maximize their profits in the face of competition through cooperation in some areas. And this cooperation effectively fosters competition on the merits in other areas. In Aspen Skiing Co., the Court made clear that a firm behaves anticompetitively when it refuses to cooperate in the face of market conditions that make cooperation essential to consumer-welfare-enhancing competition in the provision of the ultimate product. ${ }^{175}$

The Telecom Act is best viewed as a congressional finding that local telephone service, like downhill skiing in Aspen, is a market in which cooperation is necessary to enable competition to fully serve its consumer-welfare-enhancing function. Put another way, were the local telephone service market competitive, market conditions would force providers to cooperate just as market conditions encouraged the operators of Aspen's four mountains to cooperate when those mountains were independently owned.

With local telephone service, however, Congress had to overcome the chicken and egg problem. Monopoly local providers would not cooperate unless they were faced with competition. But potential competitors could not effectively enter the market without cooperation. The

174. See Covad Communications Co. v. BellSouth Corp., 299 F.3d 1272, 1286 (11th Cir. 2002) (describing BellSouth's arguments).

175. Aspen Skiing Co. v. Aspen Highlands Skiing Corp., 472 U.S. 585, 608-11 (1985). 
1996 Act addresses the chicken and egg problem by mandating the sort of cooperation that market forces would yield if they could operate. Like Aspen Skiing Company, ILECs that violate the unbundling, resale, or collocation duties of the 1996 Act eschew forms of cooperation that would normally occur in a competitive market. ${ }^{176}$ A serious violation of any of these duties should thus be entitled to the presumption that it substantially contributes to the maintenance of the ILEC's market power. Encouraging these forms of cooperation is not anticompetitive. On the contrary, it is the type of cooperation that arises when marketplace forces drive the market, and it ultimately benefits consumers. ${ }^{177}$

\section{CONCLUSION}

To a large extent, courts have always made competition policy. The open-textured language of the Sherman Act has forced them to fill the void. In the absence of an argument supporting the superiority of the judiciary over the legislature in the area of competition policy-making, however, courts should defer to legislative decisions when they can find them. ${ }^{178} \mathrm{~A}$ competition-enhancing regulatory statute like the Telecommunications Act of 1996 is an example of legislative competition policy. Courts should not assume, as the Seventh Circuit has, that such a statute frees them of their obligation to adjudicate antitrust disputes. Nor should courts assume, as the Second and Eleventh Circuits have, that they can continue to make competition policy in antitrust cases as they would in the absence of legislative guidance.

This Article proposes an analytical framework that courts can use to take proper account of competition-enhancing regulation like the 1996 Act. First, a court must ask whether imposing antitrust duties would interfere with the operation of the competition enhancing regulatory program. If antitrust duties would not undermine the regulation, a court

176. Those who disagree with the decision reached in Aspen Skiing Co. will have more difficulty recognizing the procompetitive impact of the Telecom Act. See Glen O. Robinson, On Refusing to Deal with Rivals, 87 CORNELL L. REv. 1177, 1217-23 (2002).

177. While it would be inappropriate to dismiss these claims at the pleading stage, a plaintiff's burden to prove market power and to rebut procompetitive justifications should enable a court to resolve insubstantial claims against the plaintiff at the summary judgment stage. Matsushita Elec. Indus. Co., Ltd. v. Zenith Radio Corp., 475 U.S. 574, 585-88 (1986).

178. See Jefferson Parish Hosp. v. Hyde, 466 U.S. 2, 10-11 (1984). The per se rule against tying:

reflects congressional policies underlying the antitrust laws. In enacting $\S 3$ of the Clayton Act... Congress expressed great concern about the anticompetitive character of tying arrangements.... While this case does not arise under the Clayton Act, the congressional finding made therein concerning the Id.

competitive consequences of tying is illuminating, and must be respected. 
should ask how the legislature's competition policy should influence the court's role as a policy maker in adjudicating antitrust claims. In the case of the Telecom Act, Congress has declared certain cooperative conduct procompetitive. Courts should defer to that legislative policy judgment and presume that serious violations of the Telecom Act are anticompetitive. 
